A survey of modern pollen and vegetation along an altitudinal transect in southern Georgia, Caucasus region

Connor, S.E., Thomas, I., Kvavadze, E.V., Arabuli, G.J., Avakov, H.S. and Sagona, A.

This is a draft version of a manuscript published in Review of Palaeobotany and Palynology 129: 229-250 (2004). Please note that there may be differences between this version and the final published version. The authors will be happy to provide copies on request. 


\title{
A survey of modern pollen and vegetation along an altitudinal transect in southern Georgia, Caucasus region.
}

\author{
Simon E. Connor ${ }^{\mathrm{a}^{*}}$, Ian Thomas ${ }^{\mathrm{a}}$, Eliso V. Kvavadze ${ }^{\mathrm{b}}$, Giorgi J. Arabuli ${ }^{\mathrm{c}}$, \\ Genia S. Avakov ${ }^{\mathrm{b}}$ and Antonio Sagona ${ }^{\mathrm{d}}$ \\ ${ }^{a}$ School of Anthropology, Geography and Environmental Studies, University of Melbourne, VIC 3010, \\ Australia \\ ${ }^{\mathrm{b}}$ Institute of Paleobiology, Georgian Academy of Sciences, Niagvris kucha 4a, Tbilisi 380004, Georgia \\ ${ }^{\mathrm{c} B o t a n i c a l ~ D e p a r t m e n t, ~ S t a t e ~ M u s e u m ~ o f ~ G e o r g i a, ~ G e o r g i a n ~ A c a d e m y ~ o f ~ S c i e n c e s, ~ R u s t a v e l i s ~ g a m z i r i ~}$ \\ 3, Tbilisi 0105, Georgia \\ ${ }^{\mathrm{d} S c h o o l}$ of Art History, Cinema, Classics and Archaeology, University of Melbourne, VIC 3010, \\ Australia
}

\begin{abstract}
This paper describes the pollen representation of vegetation patterns along an altitudinal transect in the South Caucasus region. Surface sediments from eight smallto medium-sized lakes and wetlands were analysed for modern pollen and the results analysed numerically using detrended correspondence analysis (DCA) and dichotomised ordination (TWINSPAN). Pollen spectra from the semidesert region have a clear palynological signal characterised by an abundance of Chenopodiaceae. Differentiation of oak forest, upper tree-line and subalpine communities is more difficult: all are dominated by arboreal pollen types. The authors propose a number of indicator pollen types and pollen threshold values that may assist in detecting tree-line variations and deforestation events in Holocene pollen diagrams.
\end{abstract}

\section{Keywords}

pollen; vegetation; climate; tree-lines; numerical analysis; Caucasus

\footnotetext{
*Corresponding author. Fax: +61 3 83444972; e-mail: s.connor@pgrad.unimelb.edu.au
} 


\section{Introduction}

The discrimination of forested and open vegetation types is a necessary prelude to any palaeoecological interpretation that aims to identify tree-line variations and deforestation events in fossil pollen spectra.

Traditionally, pollen representation studies have made use of moss polster or surface soil samples and related these to the surrounding vegetation (Bradshaw, 1981; Bunting, 2002; Davis, 1980; Elliot, 1999; Gajewski et al., 2002; Islebe and Hooghiemstra, 1995; Paez et al., 2001; Tinsley and Smith, 1974; Vermoere et al., 2000; Wright et al., 1967). Several of these have previously been undertaken in the Caucasus region, using soil or moss samples collected over long altitudinal transects (Klopotovskaya, 1973; Kvavadze, 1993; Kvavadze, 1999; Kvavadze and Efremov, 1994; Kvavadze and Efremov, 1995; Stuchlik and Kvavadze, 1995; Yazvenko, 1991). However, the application of these studies to the interpretation of fossil pollen diagrams is limited by the fact that few sites used in palaeoenvironmental reconstructions have a comparable source area to soil or moss samples (Hicks, 2001; Kvavadze and Efremov, 1995). Consequently, pollen indicators derived from soil samples and moss polsters cannot be strictly applied to the interpretation of lake and wetland sediments.

Moss polsters beneath forest canopies are dominated by pollen originating in approximately the surrounding $20-30 \mathrm{~m}$, small forest hollows by pollen from $50-100 \mathrm{~m}$, whilst sediments at the centre of large lakes may have pollen spectra dominated by a regional component derived from a source area of perhaps many hundreds of kilometres (Andersen, 1970; Calcote, 1995; Jacobson and Bradshaw, 1981; Janssen, 1966; Prentice, 1985; Sugita, 1993). 
These source area concepts are based on conditions in northern hemisphere temperate forests and may not apply to research in areas where semidesert steppes, deforested foothills and upland grasslands are characteristic vegetation types (Davies and Fall, 2001). Study sites within open landscapes have a greater potential pollen source area than those in a closed-canopy forest due to the removal of the trunk space (Tauber, 1965) or gravity component (Jacobson and Bradshaw, 1981) and the absence of filtration by arboreal vegetation (Tauber, 1967). Upland sites are typically dominated by arboreal pollen generated by lowland forests (Fall, 1992; Frei, 1997; Haberle and Bennett, 2001; Islebe and Hooghiemstra, 1995; Kvavadze, 1993; Markgraf, 1980) and determining the position of tree-lines palynologically is therefore difficult and potentially flawed (Birks and Birks, 2000).

In mountainous regions, conifer stomate analyses have shown that arboreal pollen percentages and influx rates rise as forests advance toward a study site, and often decline once forests are present in situ (Ammann and Wick, 1993; David, 1997; Pisaric et al., 2000). Human activity may also result in a greater influx of forest tree pollen, increasing arboreal pollen percentages during deforestation events (Aaby, 1988). The relationship between arboreal pollen abundance and forest abundance is therefore non-linear.

In the semi-arid regions of the Caucasus, differentiation of open versus forested conditions in late-Quaternary pollen diagrams is crucial in contextualising a rich archaeological record. Hence, this paper asks: can open and forested environments in Georgia be differentiated using modern pollen data; and, if so, are there indicator pollen specific to certain plant communities? 


\section{Study area}

Georgia is a nation bordered by mountains (Fig. 1). To the country's north, the anticlinal Greater Caucasus Mountains rise to a maximum elevation of $5642 \mathrm{~m}$ a.s.l. (Mt Elbrus); and to the south lie the volcanic Anticaucasus Uplands.

Within our study area of the Anticaucasus, the Samsari and Javakheti Ranges (Fig. 2) reach a maximum elevation of 3300m (Mt. Didi Abuli). These upperPliocene/Quaternary basaltic and andesitic ridges (Maisuradze, 1989) run perpendicular to the dominant west-to-east storm tracks originating over the Black Sea, creating a rain shadow in eastern Georgia. Annual rainfall varies from approximately $800 \mathrm{~mm}$ on the Javakheti Range to less than $400 \mathrm{~mm}$ in the steppic lowlands near the Georgian capital, Tbilisi (SSSR, 1964). May is generally the wettest month, and January the driest. Annual average winter temperatures vary considerably in the study region, from $-10^{\circ} \mathrm{C}$ in the mountains to $0^{\circ} \mathrm{C}$ in the lowlands (abs. min. $-28^{\circ} \mathrm{C}$ ), and 14 to $25^{\circ} \mathrm{C}$ in summer (abs. $\max .40^{\circ} \mathrm{C}$ ) (SSSR, 1964; Tatashidze, 2000).

The soils of the lowlands overlie Quaternary pluvio-glacial and alluvial sediments. Solonchak soils occur in enclosed synclinal depressions in the semideserts. Skeletal and peaty soils are found in alpine areas (such as the Javakheti and Samsari ridges), shallow greyish soils in the upper forest belts on basalt substrates, chestnut and brown forest soils on foothill slopes, and chernozems in both semidesert and subalpine areas (Berg, 1950; Gregory and Shave, 1944).

The vegetation of eastern Georgia (Fig. 2) falls broadly into the IranoTuranian group (Zohary, 1973). Semideserts and lowland steppes are dominated by Poaceae-Chenopodiaceae-Artemisia associations, with patches of arid open woodland 
including Pistacia mutica, Celtis caucasica, Pyrus salicifolia, Amygdalus georgica, Rhamnus pallasii, Juniperus spp., Ephedra procera and Cotinus coggygria (Dolukhanov, 1966; Nakhutsrishvili, 1999). Lower tree-line vegetation communities are highly human-impacted, corresponding broadly to Mediterranean 'garrigue' and 'maquis'. Most are former oak or oak-hornbeam woodlands that have been subjected to continuous deforestation and burning (Avakov, 1982; Badenkov et al., 1990), leading to a proliferation of fire- and herbivore-tolerant species such as Paliurus spina-christi.

The east Georgian forest belt (Fig. 2) is constricted by low rainfall, steep topography and human impact. Mixed broadleaf Quercus-Carpinus forests are dominant from the foothills to the anthropogenic upper tree-line and replaced by fragments of Fagus orientalis-dominated forest on moist north-facing slopes. Disjunct pockets of Pinus kochiana exist in rocky gorges and on steep slopes, and are thought to represent remnants of its greater distribution during glacial times (Gulisashvili, 1949). Forests of Picea orientalis and Abies nordmanniana are rare under the continental climatic regime of eastern Georgia, occurring only along the ridgeline of the Trialeti Range (Fig. 2).

Subalpine vegetation of the Tsalka and Javakheti volcanic plateaux consists of species-rich steppic grasslands dominated by Festuca ovina, Bromus spp., Koeleria cristata, Poa alpina, Nardus stricta, Carex spp. and others (Magakian, 1933). Human impact in the subalpine region is especially pronounced, under the combined effects of cattle grazing, deforestation and hay-making (Badenkov et al., 1990; Bock et al., 1995). 


\section{Methods}

We selected eight lakes and wetlands along an altitudinal transect running across southern Georgia from lowland steppe-semidesert to subalpine environments (Fig. 2, Table 1).

Sites include a semidesert salina (Sakhare Tba), a lowland salt lake (Kumisis Tba), a wetland at the steppe-forest ecotone (Tsavkisis Tba), a lake within oakhornbeam forest (Cherepanovis Tba), a small mire at the upper tree-line (Trialetis Tba), two maar lakes on the subalpine Tsalka Plateau (Imeras Tba and Baretis Tba), and a bog on the treeless Javakheti Plateau (Avchalagöl). Fluvial input into all sites is absent or minimal.

We calculated forest area values in Table 1 with reference to Sugita's model for an entire lake surface (Sugita, 1993) and forest data on 1:100000 topographic maps. To account for differences in pollen sizes, we found it useful to approximate the model by defining the $50 \%$ pollen source radius as ten times the basin radius. This weights our calculated source area from 'relatively light' to 'relatively heavy' pollen types (Sugita, 1993) such as Quercus, Carpinus, Fagus and Pinus, these being predominant in the region's forests.

At Sakhare, Tsavkisi, Cherepanovi, Trialeti and Imera, the surrounding vegetation was described and percentage aerial cover estimates were made using the Domin scale. As the layering of vegetation at forest sites produced total cover percentages in excess of $100 \%$, the forest area values (Table 1) were applied, enabling pollen percentages and vegetation percentages to be compared semi-quantitatively.

Plant nomenclature follows Czerepanov (1995). 
Surficial lake and wetland sediments were sampled to provide source-area analogues to aid the interpretation of Holocene pollen records from the same sites. Three to four samples, each comprising a composite of sediment gathered over a $5 \mathrm{x}$ $5 \mathrm{~m}$ area, were collected from each site to achieve a representative coverage. In addition, moss polsters and surface soils were collected at the oak-hornbeam forest site for comparative purposes.

Individual surface samples were homogenised before extracting $1 \mathrm{~cm}^{3}$ samples for pollen analysis. Two Lycopodium marker spore tablets (University of Lund, batch 938934) were added prior to processing. Pollen extraction involved carbonate removal in $10 \% \mathrm{HCl}$, boiling in $\mathrm{KOH}$, heavy liquid separation in Sodium polytungstate (Hart, 1988), HF treatment to digest fine silica, and acetolysis to remove dispersed organics (Moore et al., 1991). Samples were mounted in glycerol and pollen identified using type material held at the University of Melbourne and published pollen keys (Bobrov et al., 1983; Chester and Raine, 2001; Kuprianova and Aleshina, 1972; Kuprianova and Aleshina, 1978; Moore et al., 1991). Most samples were counted to a minimum of 400 terrestrial pollen grains. Charcoal fragments were quantified using the point-count method (Clark, 1982). Pollen diagrams were drawn in Psimpoll (Bennett, 2002).

Percentage pollen data were analysed using a variety of multivariate numerical methods. Only dryland taxa found in more than two samples were included in the analyses.

Weighted-averaging methods proved satisfactory as they allow for unimodal responses to environmental gradients (ter Braak and Prentice, 1988). Detrended correspondence analysis (DCA)(Hill and Gauch, 1980), a form of indirect gradient analysis, was executed using the debugged version of DECORANA (Hill, 1979a; 
Oksanen and Minchin, 1997) in Psimpoll 4.10 (Bennett, 2002). Rescaled DCA was performed on all taxa, with rare types downweighted. The results were checked with non-metric multidimensional scaling (sensu Ejrnæs, 2000) and the gradients appear to be robust.

Two-way indicator species analysis (TWINSPAN) (Hill, 1979b) was run on untransformed data in PC-ORD 4.25 (McCune and Mefford, 1999). This divisive classification method is less sensitive to the background 'noise' created by regional pollen than some other techniques. TWINSPAN produces a series of dichotomies based on a reciprocal averaging ordination similar to DCA. Samples are split into two groups at each division, based on their position on the ordination axis. At each split, the pseudospecies (quantitative presence/absence measure of a species) that best differentiates the two groups is given as an indicator. TWINSPAN indicators have considerable value for ecological interpretation and classification of the resulting groups. The maximum number of pseudospecies cut levels was selected, and rare types downweighted manually.

\section{Results and discussion}

Pollen proportions of major taxa are shown in relation to altitudinal, vegetational and climatic gradients in Figure $3 \mathrm{a} / \mathrm{b}$. The taxa are arranged according to their order in the TWINSPAN table so that the associations between, for example, Chenopodiaceae and Polygonaceae in the semidesert-steppe spectra, are apparent.

The TWINSPAN clusters and group numbers (shown in Figure 3b) show that the semidesert-steppe spectra (TWINSPAN group 3) are clearly differentiated from spectra where pollen of forest trees are more prevalent (TWINSPAN group 2). The 
analysis also differentiates between pollen spectra from forest sites (TWINSPAN group 19) and treeless subalpine sites (TWINSPAN group 18).

The species that best describes the difference between these and other groups is given as a TWINSPAN indicator, shown in Table 2. This means that TWINSPAN group 18 can be distinguished from TWINSPAN group 19 by Picea proportions greater than 1.5\%. Within TWINSPAN group 19, the oak-forest group (39) can be split from the upper tree-line group (38) by the presence of more than $2 \%$ Cerealia-type pollen in the former, and the representation of Capsella bursa-pastoris and Polygonum aviculare-type pollen in the latter.

Pollen data are discussed in relation to the vegetation and climate of the three major landscape units (semidesert-steppe, forest and subalpine) in the sections below:

\subsection{Lowland steppes and semideserts of Gareji and Lower Kartli (TWINSPAN groups 7, 6 and 10)}

Along the altitudinal transect, pollen spectra (Fig. 3a/b) show a clear response to climatic gradients (Fig. 3a). This is particularly evident in the relationship between Chenopodiaceae pollen proportions and annual rainfall.

In other parts of the Near East, Chenopodiaceae:Artemisia (C/A) ratios have been used to estimate aridity levels from pollen data (Davies and Fall, 2001; ElMoslimany, 1990). In our study area, however, C/A ratios show a relatively poor relationship to rainfall $\left(\mathrm{r}^{2}=0.34\right)$ compared to Chenopodiaceae percentages alone $\left(\mathrm{r}^{2}=0.81\right)$. This may be related to the application of $\mathrm{C} / \mathrm{A}$ ratios to lake sediments rather than soils, or the different ecology of Artemisia in the Caucasus. Artemisia pollen is more common in TWINSPAN group 6 (approx. 350mm. annual rainfall) than 
group 7 (approx. $400 \mathrm{~mm}$. annual rainfall), and is a TWINSPAN indicator of the former (Table 2).

In the study region, Artemisia fragrans is found in desert/semidesert vegetation communities, which were, until the mid- $20^{\text {th }}$ Century, relatively widespread on the arid lowlands and foothills of the eastern Caucasus (Dolukhanov, 1966). Semidesert vegetation formerly occupied areas suitable for cotton and grain agriculture, and its present distribution is relatively fragmentary, occurring mainly on saline soils (Dolukhanov, 1966).

Although a semidesert community, dominated by Artemisia fragrans and Salsola nodulosa, exists on the lake terrace of Sakhare Tba (site S, TWINSPAN group 7), it appears that the pollen representation of Chenopodiaceae is much greater than Artemisia (Table 3) and the various members of the Poaceae family. Amongst these, Festuca valesiaca and Stipa pulcherrima are dominant in the arid steppe grasslands, which are used for cattle grazing and are burnt frequently by herders to encourage fresh grass growth and restrict reestablishment of woody plants. High charcoal concentrations in the sediments (Fig. 3b) may reflect these burning practices. Polygonum aviculare-type and other Polygonaceae pollen are common in the pollen spectra, although we could not locate source plants in the surrounding vegetation.

Consistent with the predominantly-treeless landscape of the semideserts and arid steppes (Fig. 4), arboreal pollen (AP) occurs in small proportions, except in sediments from the centre of saline lake, Kumisis Tba (TWINSPAN group 10 - foreststeppe), where AP reaches $23 \%$, compared to $2 \%$ in samples taken nearer the lake edge (TWINSPAN group 6 - semidesert-steppe). Source-area differences are thought to explain this intra-basin AP variation. 


\subsection{Forests of south-eastern Georgia (TWINSPAN groups 11, 38 and 39)}

The forest cover of the eastern slopes of the Anticaucasus Mountains in Georgia is little-studied and poorly-described (Prof. R. Gagnidze, Director, Botanical Institute, Georgian Academy of Sciences, pers. comm.). Both the lower and upper tree-lines are anthropogenic (Ketskhoveli, 1959), posing particular problems for identifying tree-line analogues in modern pollen spectra and climatic shifts in fossil pollen spectra.

The forest belt is dominated by mixed broadleaf tree associations, in which Quercus iberica, Carpinus caucasica, C. orientalis and Fagus orientalis predominate. At the steppe-forest ecotone near Tsavkisis Tba (Site Ts, TWINSPAN group 11), the dominant forest type is Carpinus orientalis-Quercus iberica, and although this forms a majority of the site's surrounding vegetation, it is very poorly represented in the pollen spectra (Table 4) when compared to Pinus pollen. Pine plantations occupy approximately $20 \%$ of the wetland's calculated pollen source area. Apple orchards occupy a similar area, but are palynologically 'silent'. TWINSPAN indicators include pollen of cultivated trees (Populus, Pinus and Cedrus) and Plantago lanceolata, an anthropogenic indicator (Behre, 1986).

Chenopodiaceae pollen proportions are lower than in the steppe-semidesert sites, consistent with the higher rainfall received by this site (approx. $500 \mathrm{~mm}$ per annum). And, despite the relatively forested catchment (60\%), arboreal pollen proportions average only $27 \%$, of which Pinus pollen contributes over half.

Similarly, within the forest belt proper (Cherepanovis Tba, site C, TWINSPAN group 39), AP averages only 35\%. Sugita et al. (1999) have suggested that arboreal pollen versus non-arboreal pollen (AP:NAP) ratios are ineffective in determining 
landscape openness from pollen data, and our results confirm this. There is no relationship between AP:NAP ratios and forest cover values in this study $\left(\mathrm{r}^{2}=0.0001\right)$.

The forests surrounding Lake Cherepanovis Tba are dominated by Quercus iberica and Carpinus caucasica, with a shrubby understorey dominated by members of the Rosaceae (Table 5). Small fragments of pure Fagus orientalis forest (Fagetum nudum) are found on moist, north-facing slopes. Polydominant forests are common in the region, in which, along with the above species, Acer campestre, A. laetum, Carpinus orientalis, Cerasus avium, Crataegus curvisepala, C. pentagina, Fraxinus excelsior, Populus tremula, Pyrus caucasica, Ulmus glabra and other trees are moreor-less common. Above 1450m. elevation, mountain oak (Quercus macranthera) begins to replace the Georgian oak (Quercus iberica) in Quercus-Carpinus caucasica associations. In clearings, such as the lake terrace of Cherepanovis Tba (Fig. 5), meadow vegetation dominated by Agrostis planifolia and other grasses may be found.

Table 5 shows the relationship between vegetation composition and the pollen spectra of lake sediments from Cherepanovis Tba, moss polsters from the forest floor, and soil samples from the same forest. The pollen spectra of the lake sediments are dominated by Poaceae and Quercus (AP: 35\%), the moss polster spectra by Quercus, Carpinus caucasica and Pinus (AP: 67\%), and the soil sample spectra by Pinus, Chenopodiaceae and Quercus (AP: 43\%). These significant differences in the pollen spectra highlight the difficulties in using soil samples and moss polsters as modern analogues for lake sediment pollen records.

The TWINSPAN indicator for these oak-forest samples is Cerealia-type pollen (Table 2). The nearest agricultural land is a considerable distance from the site, so the prevalence of cereal pollen may relate to the presence of wild cereals in the area. The Caucasus is regarded as a centre of wild cereal diversity (Vavilov, 1992), and some of 
these were harvested by Neolithic populations (Kiguradze, 1986). Hillman (1996) has proposed that domestic cereals were selected from wild varieties found in QuercusRosaceae 'parklands'. Quercus and Cerealia-type pollen percentages are positivelycorrelated in samples from this study $\left(\mathrm{r}^{2}=0.44\right)$.

The upper tree-line site (Trialetis Tba, site Tr, TWINSPAN group 38) is an infilled maar lake situated directly above the Khrami River Canyon. Immediately adjacent the site is a Quercus iberica and Q. macranthera forest (on the southern slope), a secondary forest dominated by Corylus avellana, Carpinus caucasica and Fraxinus excelsior (on the northern slope), and a diverse subalpine meadow (Table 6). Forest area at this site is approximately $45 \%$, and AP levels vary between 17 and $20 \%$.

Corylus is greatly underrepresented in the pollen spectra: it is the dominant canopy tree in the secondary forest, but contributes to less than $5 \%$ of the AP sum. Pinus and Quercus are the dominant AP taxa, and the site is differentiated from the oak-forest site by the selection of the open vegetation indicators, Polygonum aviculare-type and Capsella bursa-pastoris (Hornungia-type), as TWINSPAN indicators (Table 2).

In the forest sites, charred particles (Fig. 3b) are constantly represented in sediments. Each site has an area of open grassland nearby that may be contributing this micro-charcoal, or it may derive from in-situ burning of the wetland vegetation.

\subsection{Subalpine steppic grasslands of the Tsalka and Javakheti Plateaux}

\section{(TWINSPAN groups 8, 36 and 37).}

With the exception of TWINSPAN group 8, discussed below, the subalpine sites (Imeras Tba, Baretis Tba and Avchalagöl) form subgroups 36 and 37 of TWINSPAN 
group 18, indicated by Picea proportions greater than $1.5 \%$ (Table 2). This contrasts with the forest groups, where Picea pollen is present only in trace proportions.

Picea orientalis is found in 'dark coniferous forests', common on the moist western slopes of the Anticaucasus Mountains (Nakhutsrishvili, 1999). On the drier eastern slopes (the study area), the distribution of Picea orientalis is extremely restricted, and the quantities of Picea pollen found in the subalpine sediments studied here can only be the result of long-distance pollen transport. Previous work in the Anticaucasus (Margalitadze, 1995) suggests that Picea pollen percentages are approximately equal to Pinus percentages where Picea orientalis-dominated forests are present in situ.

Pinus is the dominant AP taxon and AP percentages reach their highest levels (up to 63\%) along the entire altitudinal gradient. Pollen taxa such as Pterocarya, Buxus, Zelkova, Olea europaea, Ephedra distachya-type, E. fragilis, Pistacia and Hippophaё indicate significant long-distance pollen transport from lowland sources over 100 kilometres distant. Corylus pollen is more abundant in the sediments of Imeras Tba (site I, TWINSPAN group 37) than in the tree-line site adjacent growing populations of Corylus avellana, a particular problem for the interpretation of fossil pollen spectra.

Another problem is the importance of several members of the Poaceae family in the especially diverse wetland vegetation of Imeras Tba (Table 7), and the absolute dominance of grasses in the treeless subalpine steppes of the study region. Any change in either steppe or wetland vegetation will affect Poaceae pollen proportions, so interpretation of landscape openness in the fossil context must rest on other subalpine herbs and forbs. 
Fire is a significant human impact in the subalpine rangelands of the Anticaucasus and the mountainous regions of north-eastern Anatolia. Shepherds and cattle herders intentionally burn large tracts of the subalpine plateaux each October in order to promote fresh grass in the following spring. The subalpine grassland and some of the wetland vegetation around Imeras Tba had been burnt when we visited in 2002 (Fig. 6). The charcoal concentrations in the sediments (Fig. 3b) are surprisingly low given this fact, and must relate to the low intensity of the burns, or to the retention of charcoal fragments in the wetland fringe vegetation.

In contrast, the sediments of Avchalagöl are exceedingly rich in charred particles. A significant area of this shallow, Carex-dominated wetland had been burnt in late-2001. The two samples obtained from the burnt sections of the wetland are comprised in TWINSPAN group 8, indicated by an absence of Ranunculus-type pollen and increased proportions of Fraxinus (Table 2). Pollen of several late-flowering species present in the unburnt sections are lacking in the burnt sections, i.e: Ranunculus-type, Cichorium-type, Galium-type and Brassicaceae.

\subsection{Pollen Representation}

The relationship between vegetation and modern pollen spectra of several study sites is shown quantitatively in Tables 3-7. Based on these data, it appears that Pinus and Quercus are high pollen producers and are always well represented in pollen spectra. Fagus and Carpinus caucasica are moderate pollen producers, Carpinus orientalis and Corylus are relatively-poor pollen producers, and Fraxinus and Rosaceae are very poor. These observations are in accord with the representation factors calculated by Andersen (1970). Of the above taxa, Pinus, Corylus and Fraxinus are probably best dispersed, due to their lightweight pollen grains. As a 
result, these pollen types can be expected in most pollen spectra, regardless of their proximity to source plants.

The pollen representation of herbaceous plants appears to depend largely upon their pollination strategy. Wind-pollinated genera, such as Poaceae and Polypodiaceae, are well represented, whereas insect-pollinated Scrophulariaceae, Boraginaceae, Caryophyllaceae and Fabaceae are generally under-represented in pollen spectra. Others, such as the Chenopodiaceae, Plantaginaceae and Polygonaceae, are over-represented, occurring in almost all pollen spectra but in few vegetation surveys.

Because the use of AP:NAP ratios is unsuitable for differentiating forested and open vegetation types from pollen data in the study region, the 'background' pollen level must be estimated (Sugita et al., 1999). This is illustrated in Figure 7, which shows selected proportions of tree pollen calculated from the AP sum along the entire altitudinal transect. Pinus pollen comprises up to $35 \%$ of arboreal pollen even when it is absent from the extra-local vegetation; $35-50 \%$ when it is found nearby; and over $50 \%$ when it is present and locally-dominant.

Quercus is locally present and dominant when its AP proportions exceed 30\%; nearby or sub-dominant at 15-30\%; and at background level below 15\%. Difficulties arise when applying this method to Carpinus caucasica, Fagus and Corylus. These taxa are co-dominant in the forests of the region, but have a poorer pollen representation than Pinus and Quercus. A two-step procedure is required to determine whether these species are local or regional. Firstly, a background level of approximately $20 \%$ for Carpinus caucasica and Fagus, and 5\% for Corylus can be adopted based on the regional thresholds in Figure 7. Percentages approaching these thresholds can then be compared to other AP taxa. Where Quercus is either 'nearby' 
or 'local', and Pinus is 'absent', then we may assume that Carpinus caucasica / Fagus / Corylus are present in the local vegetation or dominant extra-locally.

These preliminary thresholds are approximate, and should be applied to fossil pollen spectra with a degree of caution as not all vegetation associations were sampled, and background levels may have varied through time in response to human impacts and climate change. For example, the establishment of extensive Pinus plantations in the past fifty years may have elevated background levels of Pinus pollen.

\subsection{Environmental gradients}

The relationship between annual rainfall and Chenopodiaceae pollen percentages has already been discussed, but additional environmental gradients were identified by Detrended Correspondence Analysis (DCA). These are shown in Figure 8(a) as vector lines. Since DCA uses the same chi-squared dissimilarity coefficient as TWINSPAN, the results can be discussed in terms of the TWINSPAN groups.

DCA Axis 1 is correlated with annual rainfall $\left(r^{2}=0.82\right)$, elevation $\left(r^{2}=0.79\right)$, summer temperature $\left(r^{2}=0.72\right)$ and longitude $\left(r^{2}=0.68\right)$. The correlations with winter temperature $\left(\mathrm{r}^{2}=0.49\right)$, summer rainfall $\left(\mathrm{r}^{2}=0.48\right)$ and winter rainfall $\left(\mathrm{r}^{2}=0.33\right)$ are weaker. The results suggest that prediction of temperature and rainfall should be possible from pollen data, although a data-set gathered from a larger spatial area would be desirable before this is done, because rainfall and temperature are autocorrelated in this analysis.

Correlations with the second axis include winter rainfall $\left(\mathrm{r}^{2}=0.41\right)$, the charred particle : dryland pollen concentration $(C P: D L P)$ ratio $\left(r^{2}=0.22\right)$ and percentage forest cover $\left(\mathrm{r}^{2}=0.22\right)$. The latter is particularly important, as the forests (TWINSPAN groups 
38,39 ) are undifferentiated from the subalpine steppes (groups $8,36,37$ ) in terms of rainfall and elevation on Axis 1. The second axis shows that forested landscapes may be distinguished from open subalpine steppes on the basis of pollen spectra.

The relationship between winter rainfall and the forest belt (TWINSPAN groups 38 and 39) is also noteworthy. In winter, dominant north-westerly winds carry moisture over the Trialeti Range to the forest sites. In summer, the generally calmer wind regime oscillates between moist northwesterlies and dry southeasterlies (SSSR, 1964). Wind trajectories are such that the forested slopes intercept orographic winter rain, whereas the flat subalpine plateaux (TWINSPAN groups $8,36,37$ ) receive less.

The relationship between the TWINSPAN groups and some individual pollen taxa is shown in Figure 8(b). Semidesert and arid steppes (groups 6, 7, 8) are characterised by pollen spectra rich in Chenopodiaceae, Polygonaceae and Polygonum aviculare-type. TWINSPAN group 10, with its large source area, occupies a place between these and the forest-steppe ecotone group (11), where Juniperus, Pinus, Cedrus, Plantago lanceolata and Polypodiaceae are important.

The forest belt $(38,39)$ is characterised by the importance of Quercus in pollen spectra, and the presence of Carpinus orientalis, Crataegus-type, Acer, Cerealia-type, Sanguisorba officinalis, Plantago media-type, Cirsium, Ranunculustype and Caryophyllaceae. The subalpine groups $(8,36,37)$ are characterised by the representation of their TWINSPAN indicator, Picea, and numerous other taxa: Betula, Pinus, Corylus, Fraxinus, Rumex, Sanguisorba minor, Dipsacus/Cephalaria, Filipendula, Polygonum bistorta, Apiaceae, Brassicaceae, etc.

The results suggest that these taxa may have indicator value in determining landscape openness from pollen data, regardless of the under-representation of 
arboreal pollen in forests and its over-representation in subalpine grasslands. The CP:DLP ratio is also associated with open sites (Fig. 8a), and charred particle analysis may provide a further proxy of landscape openness in regions where grasslands are subject to periodic anthropogenic burning and forest fires are relatively rare.

\section{Conclusion}

This paper demonstrates that climatic gradients and landscape openness can be determined from the pollen spectra of lake and wetland sediments. Previous studies in the Caucasus (Kvavadze, 1993; Stuchlik and Kvavadze, 1995) noted the inherent difficulty in distinguishing between upland open and forested sites through pollen data. In the mountains, where winds of high velocity and duration are responsible for long-distance pollen transport, and where local pollination is often entomophilous, the use of AP:NAP ratios is of little value in quantifying landscape openness.

Instead, we suggest a slightly more complex approach, based on the presence and abundance of indicator pollen types, distinctions between regional background pollen rain and local pollen production, and the use of charred particle analysis.

This procedure remains to be tested against other sites, plant communities and fossil records, but provides a strong starting-point for a more quantitative approach to pollen-based vegetation reconstructions in the South Caucasus region.

\section{Acknowledgements}

The authors would like to express their sincere gratitude to Dr. Maia Jejelava, Dr. Oleg Bendukidze and Mr. Michael Fletcher for their help in the field. Many thanks also to Dr. Zaal Kikodze (Tbilisi State University) for arranging transport and maps, and to our ever-patient drivers from the Georgian State Museum, Kako and 
Tariel. Fieldwork was supported by the Melbourne Scholarships Office and the Faculty of Arts, University of Melbourne, and an AINSE PGR award.

This paper is dedicated to the memory of Dr. Tamaz Kiguradze, a friend and Neolithic archaeologist whose international vision and spirit of collaboration provided the impetus for this project.

\section{References}

Aaby, B., 1988. The cultural landscape as reflected in percentage and influx pollen diagrams from two Danish ombrotrophic mires. In: H.H. Birks, H.J.B. Birks, P.E. Kaland and D. Moe (Editors), The Cultural Landscape: past, present and future. Cambridge University Press, Cambridge, pp. 209-228.

Ammann, B. and Wick, L., 1993. Analysis of fossil stomata of conifers as indicators of the alpine tree line fluctuations during the Holocene. In: B. Frenzel (Editor), Oscillations of the Alpine and Polar Tree Limits in the Holocene. Paläoklimaforschung. Gustav Fischer Verlag, Stuttgart, pp. 175-185.

Andersen, S.T., 1970. The relative pollen productivity and pollen representation of North European trees, and correction factors for tree pollen spectra, determined by surface pollen analyses from forests. Danmarks Geologiske Undersøgelse, 96: 1-99.

Avakov, G.S., 1982. Estestvennoe vosstanovlenie lesov v okrestnostiakh Tbilisi. Priroda, 11: 43-49.

Badenkov, Y.P., Borunov, A.K., Mandych, A.F., Romashkevich, A.I. and Targulian, V.O., 1990. Caucasia. In: B.L. Turner, II (Editor), The Earth as transformed by Human Actions: global and regional changes in the biosphere over the past 300 years. Cambridge University Press, Cambridge, pp. 513-531.

Behre, K.-E., 1986. The interpretation of anthropogenic indicators in pollen diagrams. Pollen et Spores, 23: 225-245.

Bennett, K.D., 2002. Psimpoll 4.10. Department of Earth Sciences, Uppsala Universitet. 
Berg, L.S., 1950. Natural Regions of the U.S.S.R. Macmillan, New York, 436 pp.

Birks, H.H. and Birks, H.J.B., 2000. Future uses of pollen analysis must include plant macrofossils. Journal of Biogeography, 27: 31-35.

Bobrov, A.E., Kuprianova, L.A., Litvintseva, M.V. and Tarasevich, V.F., 1983. Spory i Pyl'tsa. Nauka, Leningrad, 208 pp.

Bock, J.H., Jolls, C.L. and Lewis, A.C., 1995. The effects of grazing on alpine vegetation: a comparison of the central Caucasus, Republic of Georgia, with the Colorado Rocky Mountains, U.S.A. Arctic and Alpine Research, 27(2): 130-136.

Bradshaw, R.H.W., 1981. Modern pollen-representation factors for woods in southeast England. Journal of Ecology, 69: 45-70.

Bunting, M.J., 2002. Detecting woodland remnants in cultural landscapes: modern pollen deposition around small woodlands in northwest Scotland. The Holocene, 12: 291-301.

Calcote, R., 1995. Pollen source area and pollen productivity: evidence from forest hollows. Journal of Ecology, 83: 591-602.

Chester, P.I. and Raine, J.I., 2001. Pollen and spore keys for Quaternary deposits in the northern Pindos Mountains, Greece. Grana, 40: 299-387.

Clark, R.L., 1982. Point count estimation of charcoal in pollen preparations and thin sections of sediments. Pollen et Spores, 24(3-4): 523-535.

Czerepanov, S.K., 1995. Vascular Plants of Russia and Adjacent States (the former USSR). Cambridge University Press, Cambridge, 516 pp.

David, F., 1997. Holocene tree limit history in the northern French Alps: stomata and pollen evidence. Review of Palaeobotany and Palynology, 97: 227-237.

Davies, C.P. and Fall, P.L., 2001. Modern pollen precipitation from an elevational transect in central Jordan and its relationship to vegetation. Journal of Biogeography, 28: 1195-1210.

Davis, A.M., 1980. Modern pollen spectra from the tundra-boreal forest transition in northern Newfoundland, Canada. Boreas, 9: 89-100. 
Dolukhanov, A.G., 1966. Rastitel'nostii Pokrov, Kavkaz. Nauka, Moscow, pp. 223251.

Ejrnæs, R., 2000. Can we trust gradients extracted by Detrended Correspondence Analysis? Journal of Vegetation Science, 11: 565-572.

Elliot, M.B., 1999. Modern pollen-vegetation relationships in Northland, New Zealand. New Zealand Journal of Botany, 37: 131-148.

El-Moslimany, A.P., 1990. Ecological significance of common nonarboreal pollen: examples from drylands of the Middle East. Review of Palaeobotany and Palynology, 64: 343-350.

Fall, P.L., 1992. Spatial patterns of atmospheric pollen dispersal in the Colorado Rocky Mountains, USA. Review of Palaeobotany and Palynology, 74: 293313.

Frei, T., 1997. Pollen distribution at high elevation in Switzerland: evidence for medium range transport. Grana, 36: 34-38.

Gajewski, K. et al., 2002. Modern climate-vegetation-pollen relations in Africa and adjacent areas. Quaternary Science Reviews, 21: 1611-1631.

Gregory, J.A. and Shave, D.W., 1944. The U.S.S.R.: a geographical survey. Harrap, London, $636 \mathrm{pp}$.

Gulisashvili, V.Z., 1949. Zakonomernoct' rasprostraneniia sosny obyknovennoi Pinus hamata Sosn. (P. silvestris V. hamata) Stev. v Zakavkaz'e. Vestnik Tbilisskogo Botanicheskie sada AN GSSR, 58.

Haberle, S.G. and Bennett, K.D., 2001. Modern pollen rain and lake mud-water interface geochemistry along environmental gradients in southern Chile. Review of Palaeobotany and Palynology, 117: 93-107.

Hart, D.M., 1988. A safe method for the extraction of plant opal from sediments. Search, 19: 293-294.

Hicks, S., 2001. The use of annual arboreal pollen deposition values for delimiting tree-lines in the landscape and exploring models of pollen dispersal. Review of Palaeobotany and Palynology, 117: 1-29. 
Hill, M.O., 1979a. DECORANA: a FORTRAN program for detrended correspondence analysis and reciprocal averaging. Cornell University, Ithaca, NY.

Hill, M.O., 1979b. TWINSPAN: a FORTRAN program for arranging multivariate data on an ordered two-way table by classification of the individuals and attributes. Cornell University, Ithaca, NY.

Hill, M.O. and Gauch, H.G., 1980. Detrended correspondence analysis: an improved ordination technique. Vegetatio, 42: 47-58.

Hillman, G., 1996. Late Pleistocene changes in wild plant-foods available to huntergatherers of the northern Fertile Crescent: possible preludes to cultivation. In: D.R. Harris (Editor), The Origins and Spread of Agriculture and Pastoralism in Eurasia. Smithsonian Institution Press, Washington D.C., pp. 159-203.

Islebe, G.A. and Hooghiemstra, H., 1995. Recent pollen spectra of highland Guatemala. Journal of Biogeography, 22: 1091-1099.

Jacobson, G.L., Jr. and Bradshaw, R.H.W., 1981. The selection of sites for palaeovegetational studies. Quaternary Research, 16: 80-96.

Janssen, C.R., 1966. Recent pollen spectra from the deciduous and coniferousdeciduous forests of northeastern Minnesota: a study in pollen dispersal. Ecology, 47: 804-825.

Ketskhoveli, N., 1959. Sakartvelos Mtsenareuli Sapari. SSSR Metsnierebata Akademiis Gamomtsemloba, Tbilisi, 441 pp.

Kiguradze, T., 1986. Neolithische Siedlungen von Kvemo-Kartli, Georgien. Materialien zur Allgemeinen und Vergleichenden Archäologie, 29. Verlag C.H. Beck, München, 121 pp.

Klopotovskaya, N.B., 1973. Osnovnye zakonomernosti formirovaniia sporovopyl'tsevykh spektrov v gornykh raionakh Kavkaza. Metsniereba, Tbilisi, 183 pp.

Kuprianova, L.A. and Aleshina, L.A., 1972. Pyl'tsa i Spory Rastenii. Nauka, Leningrad, $170 \mathrm{pp}$. 
Kuprianova, L.A. and Aleshina, L.A., 1978. Pyl'tsa Dvudol'nykh Rastenii. Nauka, Leningrad, $184 \mathrm{pp}$.

Kvavadze, E.V., 1993. On the interpretation of subfossil spore-pollen spectra in the mountains. Acta Palaeobotanica, 33(1): 347-360.

Kvavadze, E.V., 1999. The first results of the pollen monitoring programme in the Caucasus mountains (Georgia). Acta Palaeobotanica, 39(1): 171-177.

Kvavadze, E.V. and Efremov, Y.V., 1994. Palynological studies of Holocene lake sediments in the headwaters of the river Bezymianka (west Caucasus). Acta Palaeobotanica, 34(2): 205-214.

Kvavadze, E.V. and Efremov, Y.V., 1995. Peculiarities of recent pollen spectra of lake sediments in the Caucasus. Acta Palaeobotanica, 35(1): 57-72.

Magakian, A.K., 1933. K kharakteristike rastitel'nosti vysokogornykh pastbishch Taparavanskogo raiona Dzhavakhetii. In: Dzhavakhetiia - materialy po izucheniiu prirodnykh resursov Akhalkalakskogo Nagor'ia. Zak-GIZ, Tiflis, pp. 239-278.

Maisuradze, G.M., 1989. Anthropogene of the Anticaucasus. Palaeogeography, Palaeoclimatology, Palaeoecology, 72: 53-61.

Margalitadze, N.A., 1995. Istoriia golotsenovoi rastitel'nosti Gruzii. Rastitel'nosti Gruzii. Metsniereba, Tbilisi, 192 pp.

Markgraf, V., 1980. Pollen dispersal in a mountain area. Grana, 19: 127-146.

McCune, B. and Mefford, M.J., 1999. PC-ORD: Multivariate Analysis of Ecological Data. MjM Software Design, Gleneden Beach, Oregon.

Moore, P.D., Webb, J.A. and Collinson, M.E., 1991. Pollen Analysis. Blackwell Science Publishers, Oxford, 216 pp.

Nakhutsrishvili, G.S., 1999. The vegetation of Georgia (Caucasus). Braun-Blanquetia, 15: 1-68.

Oksanen, J. and Minchin, P., 1997. Instability of ordination results under changes in input data order: explanations and remedies. Journal of Vegetation Science, 8: 447-454. 
Paez, M.M., Schäbitz, F. and Stutz, S., 2001. Modern pollen-vegetation and isopoll maps in southern Argentina. Journal of Biogeography, 28: 997-1021.

Pisaric, M.F.J., Szeicz, J.M., Karst, T. and Smol, J.P., 2000. Comparison of pollen and stomates as indicators of alpine treelines in northwestern Canadian lake sediments. Canadian Journal of Botany, 78: 1180-1186.

Prentice, I.C., 1985. Pollen representation, source area, and basin size: toward a unified theory of pollen analysis. Quaternary Research, 23: 76-86.

SSSR, 1964. Sakartvelos Sabch'ota Sotsialist'uri Resp'ublik'is At'lasi. Georgian Academy of Sciences, Tbilisi, 270 pp.

Stuchlik, L. and Kvavadze, E.V., 1995. On the problem of actuopalynology in the Carpathians and Caucasus. Acta Palaeobotanica, 35(1): 73-83.

Sugita, S., 1993. A model of pollen source area for an entire lake surface. Quaternary Research, 39: 239-244.

Sugita, S., Gaillard, M.-J. and Broström, A., 1999. Landscape openness and pollen records: a simulation approach. The Holocene, 9(4): 409-421.

Tatashidze, Z. (Editor), 2000. Sakartvelos Geograpia, 1. Metsniereba, Tbilisi, 314 pp.

Tauber, H., 1965. Differential pollen dispersion and the interpretation of pollen diagrams. Danmarks Geologiske Undersøgelse. II Række, 89.

Tauber, H., 1967. Investigations of the mode of pollen transfer in forested areas. Review of Palaeobotany and Palynology, 3: 277-286.

ter Braak, C.J.F. and Prentice, I.C., 1988. A theory of Gradient Analysis. Advances in Ecological Research, 18: 271-317.

Tinsley, H.M. and Smith, R.T., 1974. Surface pollen studies across a woodland/heath transition and their application to the interpretation of pollen diagrams. New Phytologist, 73: 547-565.

Vavilov, N.I., 1992. Origin and Geography of Cultivated Plants. Cambridge University Press, Cambridge, 498 pp.

Vermoere, M., Vanhecke, L., Waelkens, M. and Smets, E., 2000. A comparison between modern pollen spectra of moss cushions and Cundill pollen traps. Grana, 39: 146-158. 
Wright, H.E., Jr., McAndrews, J.H. and van Zeist, W., 1967. Modern pollen rain in western Iran, and its relation to plant geography and Quaternary vegetational history. Journal of Ecology, 55: 415-443.

Yazvenko, S.B., 1991. Modern pollen-vegetation relationships on the Southeast Caucasus. Grana, 30: 350-356.

Zohary, M., 1973. Geobotanical Foundations of the Middle East. Verlag, Stuttgart, $739 \mathrm{pp}$.

Table 1. Site locations and associated environmental variables. See text for an explanation of forest area calculations. Type: L- lake site, W- wetland site.

\begin{tabular}{|c|c|c|c|c|c|c|c|}
\hline $\begin{array}{l}\text { Site } \\
\text { code }\end{array}$ & Site name & Type & $\begin{array}{l}\text { Location } \\
\text { (Lat.; Long.) }\end{array}$ & $\begin{array}{l}\text { Elevation } \\
\text { (m a.s.1.) }\end{array}$ & $\begin{array}{l}\text { Basin } \\
\text { avg. } \\
\text { radius (m) }\end{array}$ & $\begin{array}{l}\text { Forest } \\
\text { area }(\%)\end{array}$ & Vegetation type \\
\hline $\mathrm{S}$ & Sakhare tba & $\mathrm{W}$ & $41^{\circ} 35^{\prime} \mathrm{N} ; 45^{\circ} 19^{\prime} \mathrm{E}$ & 800 & 190 & 0 & Semidesert/steppe \\
\hline K & Kumisis tba & $\mathrm{L}$ & $41^{\circ} 35^{\prime} \mathrm{N} ; 44^{\circ} 50^{\prime} \mathrm{E}$ & 469 & 1070 & $<1$ & Semidesert/steppe \\
\hline Ts & Tsavkisis tba & W & $41^{\circ} 41^{\prime} \mathrm{N} ; 44^{\circ} 45^{\prime} \mathrm{E}$ & 1100 & 100 & 60 & Steppe/forest \\
\hline $\mathrm{C}$ & Cherepanovis tba & $\mathrm{L} / \mathrm{W}$ & $41^{\circ} 34^{\prime} \mathrm{N} ; 44^{\circ} 22^{\prime} \mathrm{E}$ & 1400 & 210 & 70 & Mixed forest \\
\hline $\operatorname{Tr}$ & Trialetis tba & $\mathrm{W}$ & $41^{\circ} 32 \mathrm{~N} ; 44^{\circ} 07^{\prime} \mathrm{E}$ & 1520 & 140 & 45 & Upper tree-line \\
\hline I & Imeras tba & $\mathrm{L} / \mathrm{W}$ & $41^{\circ} 39^{\prime} \mathrm{N} ; 44^{\circ} 12^{\prime} \mathrm{E}$ & 1600 & 140 & 0 & Subalpine steppe \\
\hline B & Baretis tba & $\mathrm{L} / \mathrm{W}$ & $41^{\circ} 39^{\prime} \mathrm{N} ; 44^{\circ} 10^{\prime} \mathrm{E}$ & 1620 & 620 & $<5$ & Subalpine steppe \\
\hline A & Avchalagöl & $\mathrm{W}$ & $41^{\circ} 20^{\prime} \mathrm{N} ; 43^{\circ} 42^{\prime} \mathrm{E}$ & 2050 & 417 & $<1$ & Subalpine steppe \\
\hline
\end{tabular}

Table 2. Positive 'perfect' indicators for TWINSPAN groups in Figure 3b. Each indicator occurs only in that group at the stipulated level. Groups not included in the table have no positive TWINSPAN indicators, hence an absence of the indicator of the opposite group may be used.

\begin{tabular}{lll}
\hline $\begin{array}{l}\text { TWINSPAN } \\
\text { group }\end{array}$ & $\begin{array}{l}\text { Ecological } \\
\text { interpretation }\end{array}$ & TWINSPAN indicators and their cut levels \\
\hline 2 & Forest and upland & Quercus 1\%; Pinus 2, 3\% \\
5 & Steppe-forest & Chenopodiaceae 10\%; Populus $>0 \%$
\end{tabular}


Lowland steppe

Semidesert/steppe

Subalpine (burnt)

Subalpine and

forest (unburnt)

Steppe-forest

Subalpine steppe

Subalpine steppe

Upper tree-line

Oak forest
Artemisia 2\%; Aster-type 0.5, 1\%; Lamiaceae 2\%; Juglans $>0 \%$

Primulaceae $1.5 \%$

Fraxinus 2\%

Ranunculus $>0 \%$

Cedrus $>0 \%$; Pinus 5, 10\%; Picea 0.5\%; Poaceae 10\%; Plantago lanceolata $>0,0.5,1 \%$

Picea $1.5 \%$

Fagus 5\%; Quercus 5\%; Carpinus caucasica 5\%

Polygonum aviculare $>0,0.5,1 \%$; Capsella bursa-pastoris $>0 \%$

Cerealia-type $2 \%$

Table 3. Plant community composition and pollen spectra at semidesert site Sakhare Tba (Site S). The table compares the cover abundance ('\% cover') of plant species to the abundance of corresponding pollen types ('\% pollen'), the values indicated by shading (see legend). Blank spaces indicate that no corresponding pollen types were found. Inverted commas (") indicate that the pollen taxon represents several of the plant species listed, e.g: Poaceae pollen represents Agropyron, Alopecurus, Bromus and other grasses.

\section{Sakhare Tba}

Herbaceous plants:

Achillea micrantha

Artemisia fragrans

Carduus albidus

Carduus seminudus

Cousinia macroptera

Cousinia orientalis

Onopordum acanthium

Senecio vernalis

Anchusa italica

Camelina microcarpa

Rorippa prostrata

Thlaspi arvense

Chenopodium album

Salsola nodulosa

Astragalus stevenianus

Lathyrus hirsuta

Medicago orbicularis

Trigonella orthoceras

Erodium cicutarium

Salvia nemorosa

Salvia viridis

Papaver fugax

Agropyron cristatum

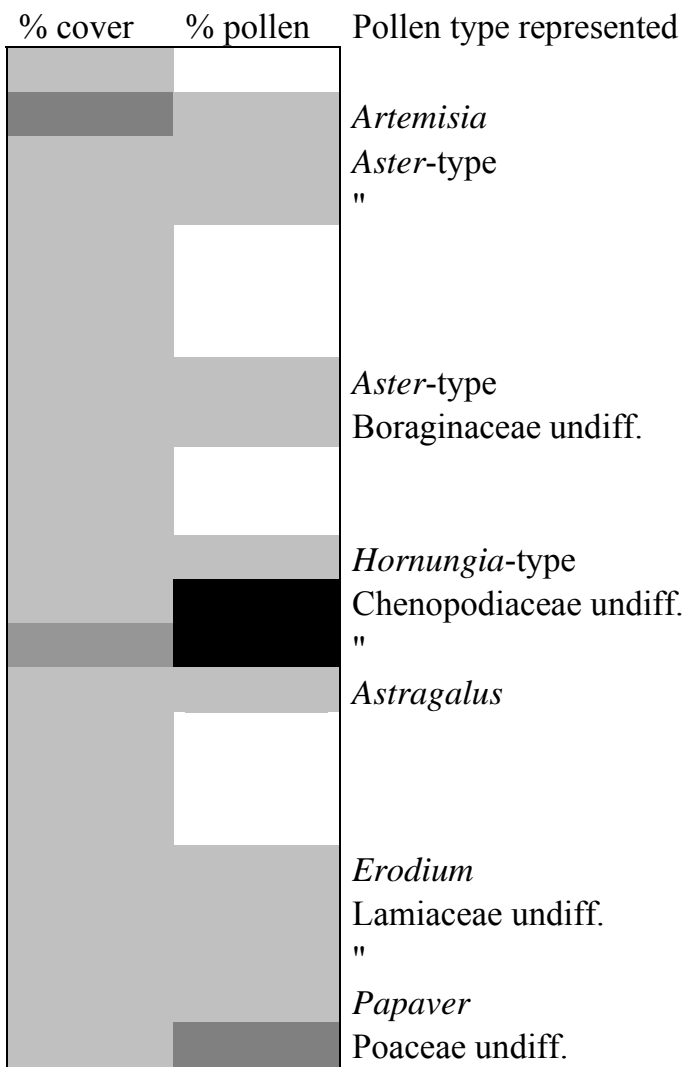


Alopecurus pratensis Bromus japonicus Dactylis glomerata Eragrostis starosselskyi Festuca valesiaca Hordeum leporinum Lolium rigidum Puccinellia gigantea Stipa pulcherrima Adonis aestivalis Reseda lutea Verbascum phoeniceum Wetland plants:

Salicornia europaea Bolboschoenus maritimus Phragmites australis

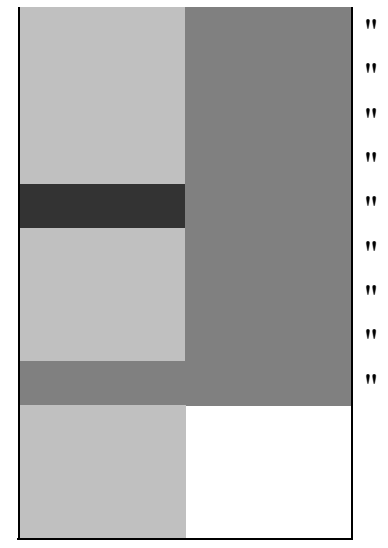

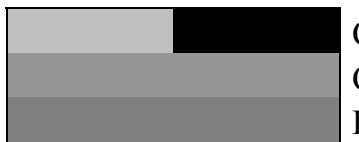

henopodiaceae undiff. Cyperaceae undiff. Poaceae undiff.

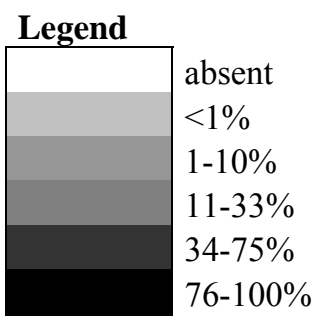

Table 4. Plant community composition and pollen spectra at lower tree-line site Tsavkisis Tba (Site

Ts). See Table 3 for explanation and legend.

\section{Tsavkisis Tba}

Trees and shrubs: Acer laetum

Lonicera caucasica Viburnum lantana

Cornus mas

Carpinus orientalis

Fagus orientalis

Quercus iberica

Juglans regia*

Fraxinus excelsior

Ligustrum vulgare

Pinus kochiana*

Malus domestica*

Malus orientalis

Prunus spinosa

Rosa canina

Rubus caesius

Populus canadensis*

Herbaceous plants:

Alisma arcuatum

Crepis micrantha

Senecio vernalis

Lappula barbata

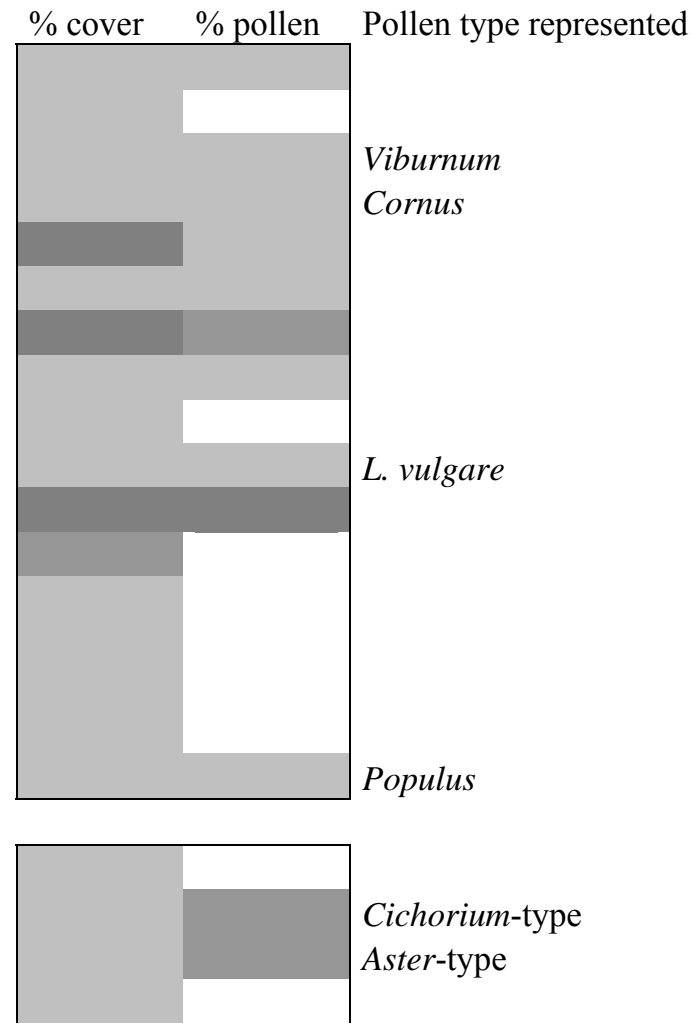


Hesperis matronalis

Campanula collina

Silene viscosa

Euphorbia helioscopia

Astragalus viciifolius

Onobrychis transcaucasica

Scutellaria galericulata

Aegilops cylindrica

Bromopsis riparia

Koeleria cristata

Melica picta

Melica taurica

Nardurus krausei

Rumex acetosella

Asplenium trichomanes

Polypodium vulgare

Polystichum braunii

Trollius ranunculinus

Geum urbanum

Asperula arvensis

Digitalis ferruginea

Veronica jacquinii

Veronica serphyllifolia

Hyosciamus niger

Wetland plants:

Carex vesicaria

Phragmites australis

Typha latifolia
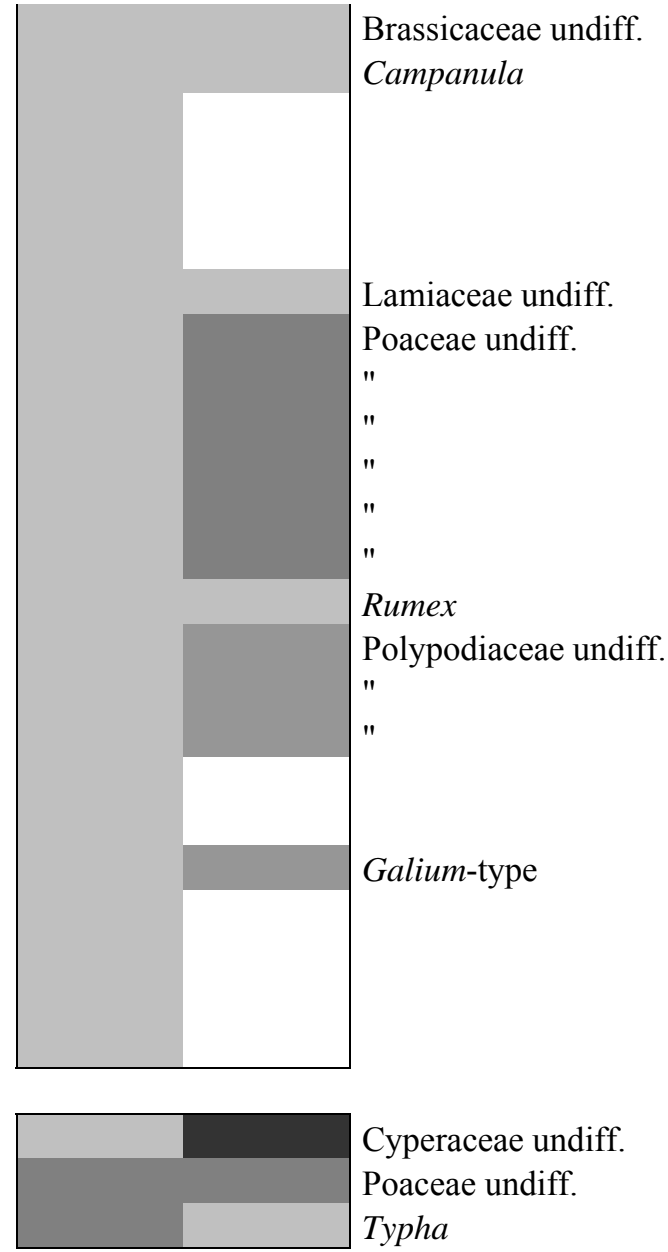

Cyperaceae undiff.

Poaceae undiff.

Typha

Table 5. Plant community composition and pollen spectra at oak-hornbeam forest site Cherepanovis

Tba (Site C). Pollen spectra of various media are compared: “\% pollen” refers to pollen spectra of lake

sediments, "\% moss" to pollen spectra of moss polsters gathered in the nearby forest, and "\% soil" to

the pollen spectra of soil samples from the same forest. See Table 3 for additional explanatory notes.

\section{Cherepanovis Tba}

Trees and shrubs:

Carpinus caucasica

Carpinus orientalis

Fagus orientalis

Quercus iberica

Cerasus avium

Crataegus curvisepala

Crataegus pentagina

Malus orientalis

Prunus divaricata

Pyrus caucasicus

Rosa canina

Populus tremula

Salix caprea

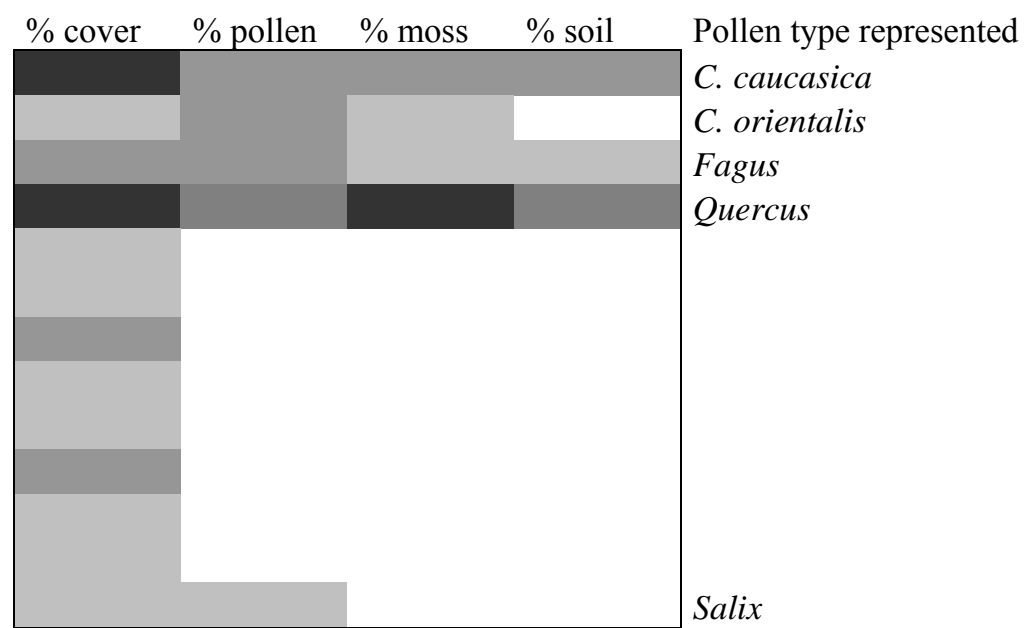

Herbaceous plants: 
Astrantia maxima

Chaerophyllum aureum

Lapsana grandis

Sonchus palustre

Arnebia pulchra

Lithospermum sibthorpianum

Scleranthus annuus

Galega orientalis

Trifolium pratense

Hypericum perforatum

Phlomis pungens

Salvia nemorosa

Marrubium goktschaicum

Ajuga genevensis

Dactylorhiza euxina

Agrostis planifolia

Deschampsia parviflora

Poa palustris

Dactylis glomerata

Erempoa persica

Koeleria cristata

Poa sylvatica

Polygala transcaucasica

Adonis vernalis

Pedicularis comosa

Veronica beccabunga

Wetland plants:

Carex vesicaria

Phragmites australis

Typha latifolia

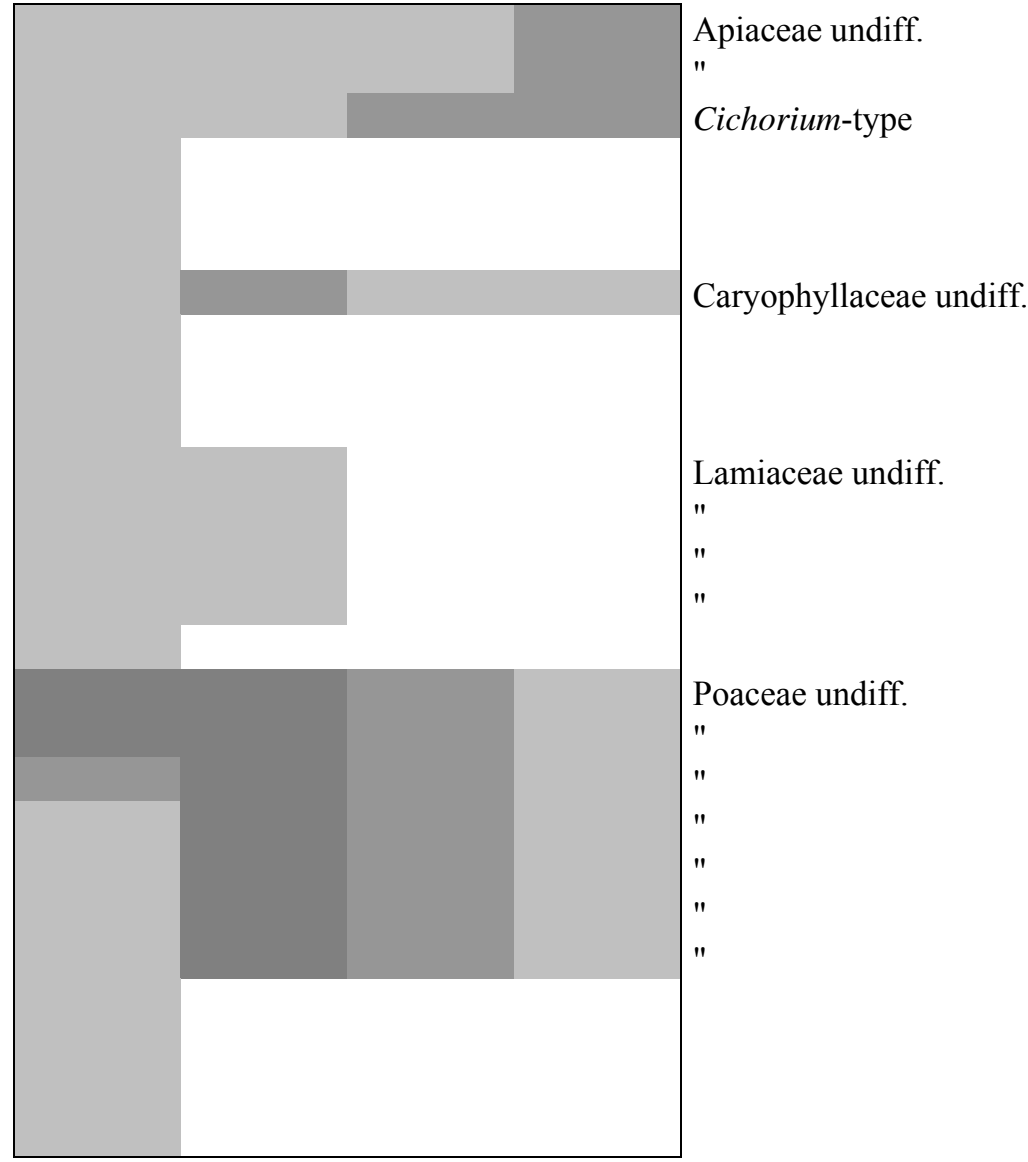

Aquatic plants:

Lemna trisulca

Nymphaea candida

Potamogeton lucens

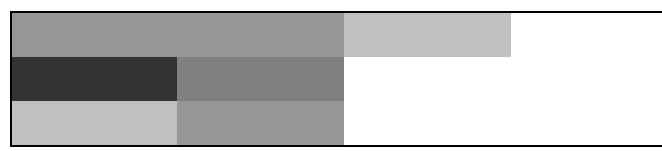

Cyperaceae undiff.

Poaceae undiff. Typha

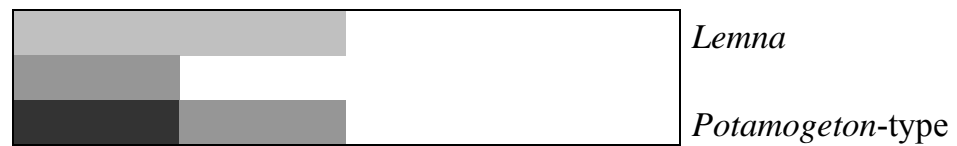

Table 6. Plant community composition and pollen spectra at upper tree-line site Trialetis Tba (Site Tr).

See Table 3 for explanation and legend.

\section{Trialetis Tba}

Trees and shrubs:

Lonicera caucasica

Lonicera steveniana

Carpinus caucasica

Carpinus orientalis

Corylus avellana

Corylus colurna

Quercus iberica

Quercus macranthera

Fagus orientalis

Fraxinus excelsior

Rhamnus catharticus

Crataegus curvisepala

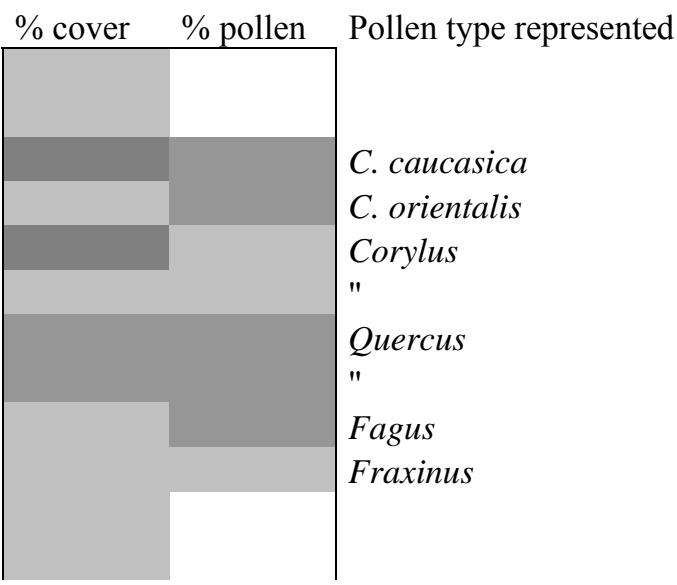


Rosa canina

Sorbus boissierii

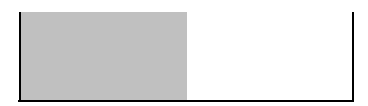

Herbaceous plants:

Sonchus palustris

Pulmonaria dacica

Capsella bursa-pastoris

Scleranthus annuus

Marrubium goktschaicum

Phlomis pungens

Asphodeline lutea

Polygonatum verticillatum

Alopecurus sericeus

Bromopsis riparia

Dryopteris filix-mas

Trollius ranunculinus

Alchemilla valdehirsuta

Asperula taurina

Veronica arvensis

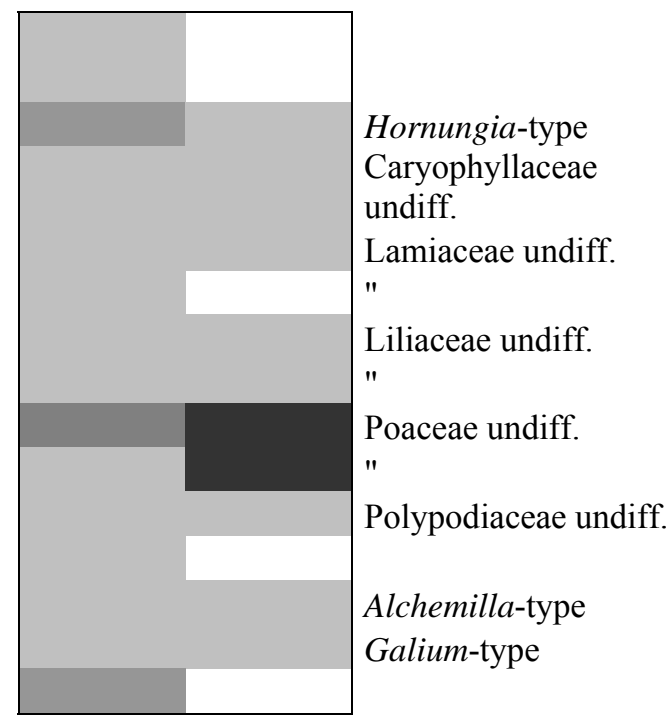

Wetland plants:

Equisetum palustre

Juncus articulatus

Phragmites australis

Potamogeton nodosus

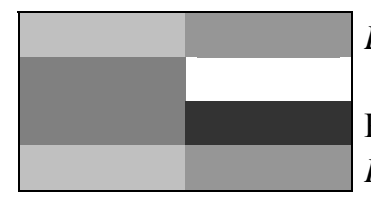

Equisetum

Poaceae undiff.

Potamogeton-type

Table 7. Plant community composition and pollen spectra at subalpine steppic grassland site Imeras

Tba (Site I). See Table 3 for explanation and legend.

\section{Imeras Tba}

Herbaceous plants:

Achillea setacea

Arctium lappa

Centaurea salicifolia

Cichorium intybus

Grossheimia macrocephala

Inula aspera

Taraxacum praticola

Anchusa gmelenii

Capsella bursa-pastoris

Clypeola jonthlaspi

Erophila verna

Scleranthus annuus

Cephalaria gigantea

Euphorbia villosa

Trifolium pratense

Vicia purpurea

Vicia variabilis

Gentiana gelida

Anacamptis pyramidalis

Agrostis planifolia

Phleum phleoides

Phleum pratense

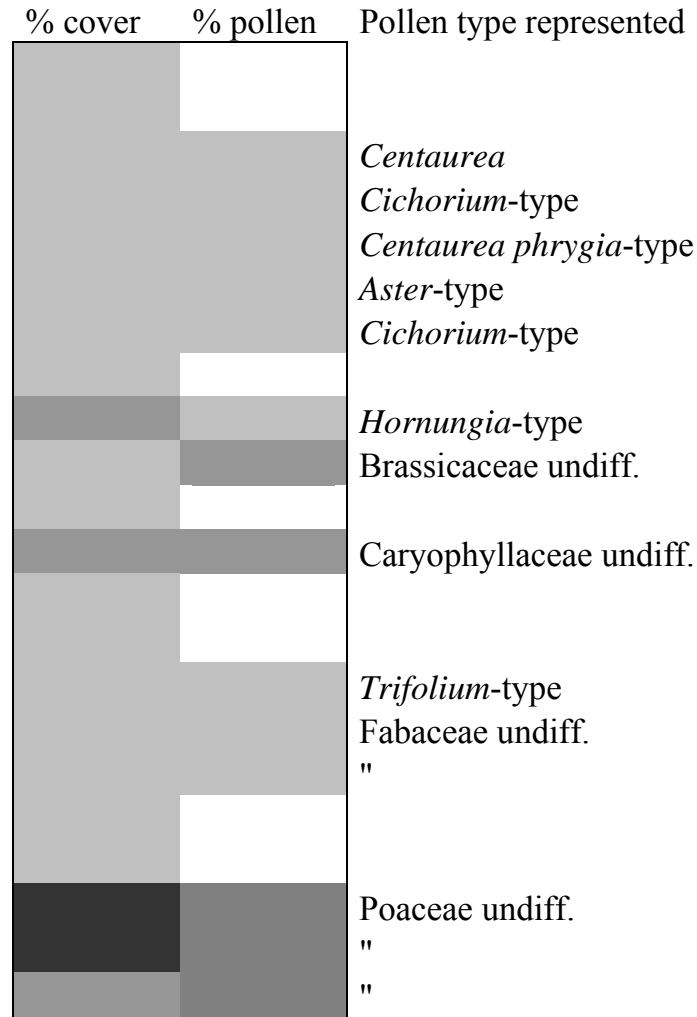


Dactylis glomerata

Deschampsia parviflora

Poa pratensis

Alopecurus aequalis

Polygala transcaucasica

Rumex acetosella

Trollius ranunculinus

Alchemilla erythropoda

Sanguisorba officinalis

Asperula caucasica

Galium verum

Rubia tinctorum

Digitalis ferruginea

Pedicularis comosa

Pedicularis condensata

Rynchocorys elephas

Veronica anagallis-aquatica

Viola montana

Wetland plants:

Alisma plantago-aquatica

Sagittaria sagittifolia

Carex dichroandra

Scirpus lacustris

Carex vesicaria

Juncellus pannonicus

Juncus effusus

Mentha arvensis

Stachys palustris

Epilobium hirsutum

Phragmites australis

Scolochloa festucacea

Calamagrostis neglecta

Poa palustris

Typha latifolia

Aquatic plants:

Myriophyllum spicatum

Nymphaea candida

Polygonum amphibium

Potamogeton gramineus

Potamogeton lucens

Potamogeton natans

Sparganium minimum

Sparganium neglectum
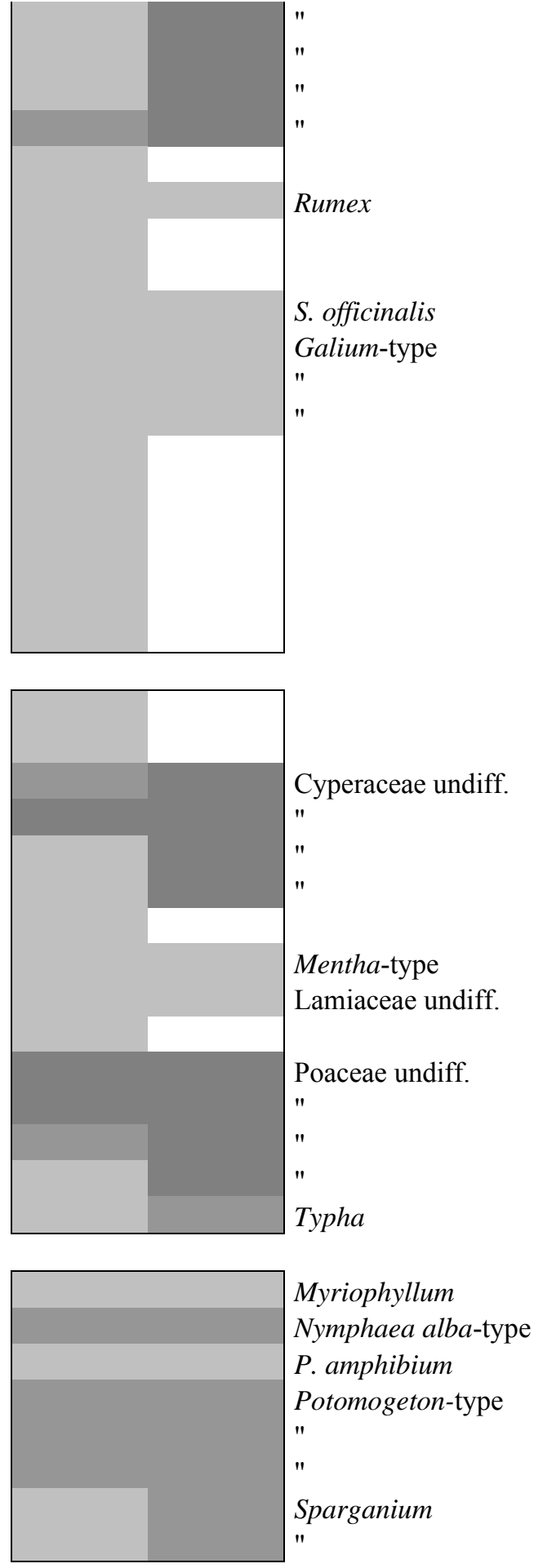


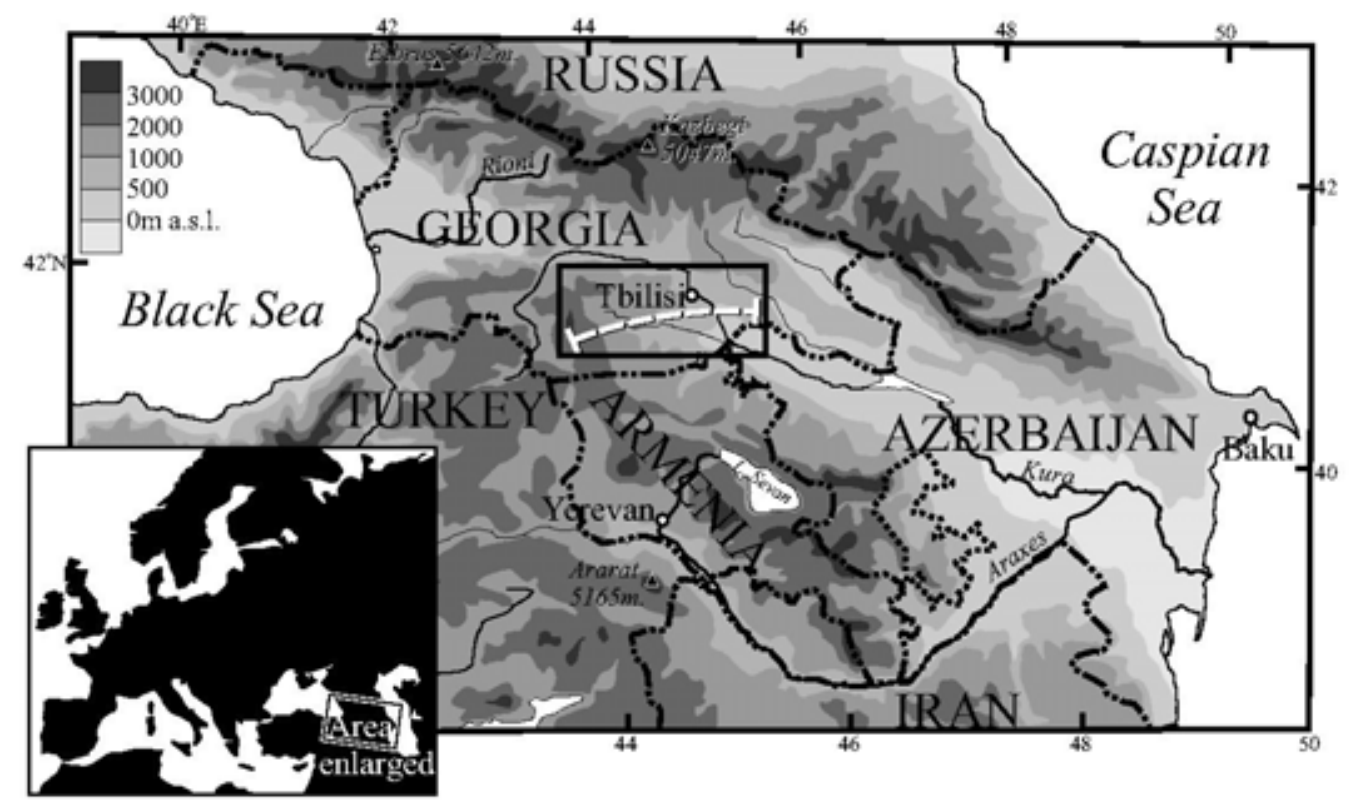

Figure 1. Topographic map of the South Caucasus region. Boxed area around Tbilisi indicates the study area enlarged in Fig. 2. The white dashed line indicates the position of the altitudinal transect shown in Fig. 3a.

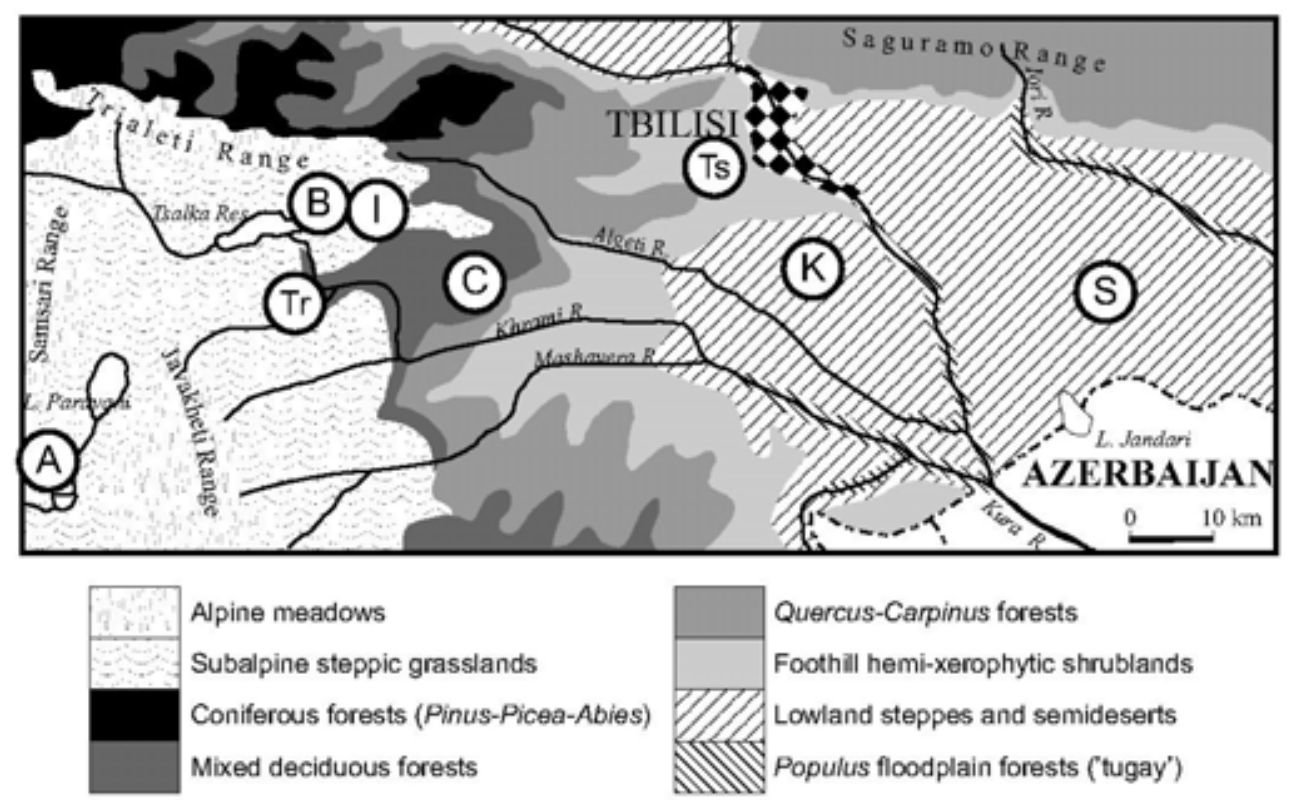

Figure 2. Map of principal vegetation types in the study area of southern Georgia, including study sites discussed in this paper. Site codes: S- Sakhare Tba, K- Kumisis Tba, Ts- Tsavkisis Tba, C-

Cherepanovis Tba, Tr- Trialetis Tba, I- Imeras Tba, B- Baretis Tba, A- Avchalagöl. Adapted from SSSR Atlas (1964) and Ketskhoveli (1959). 


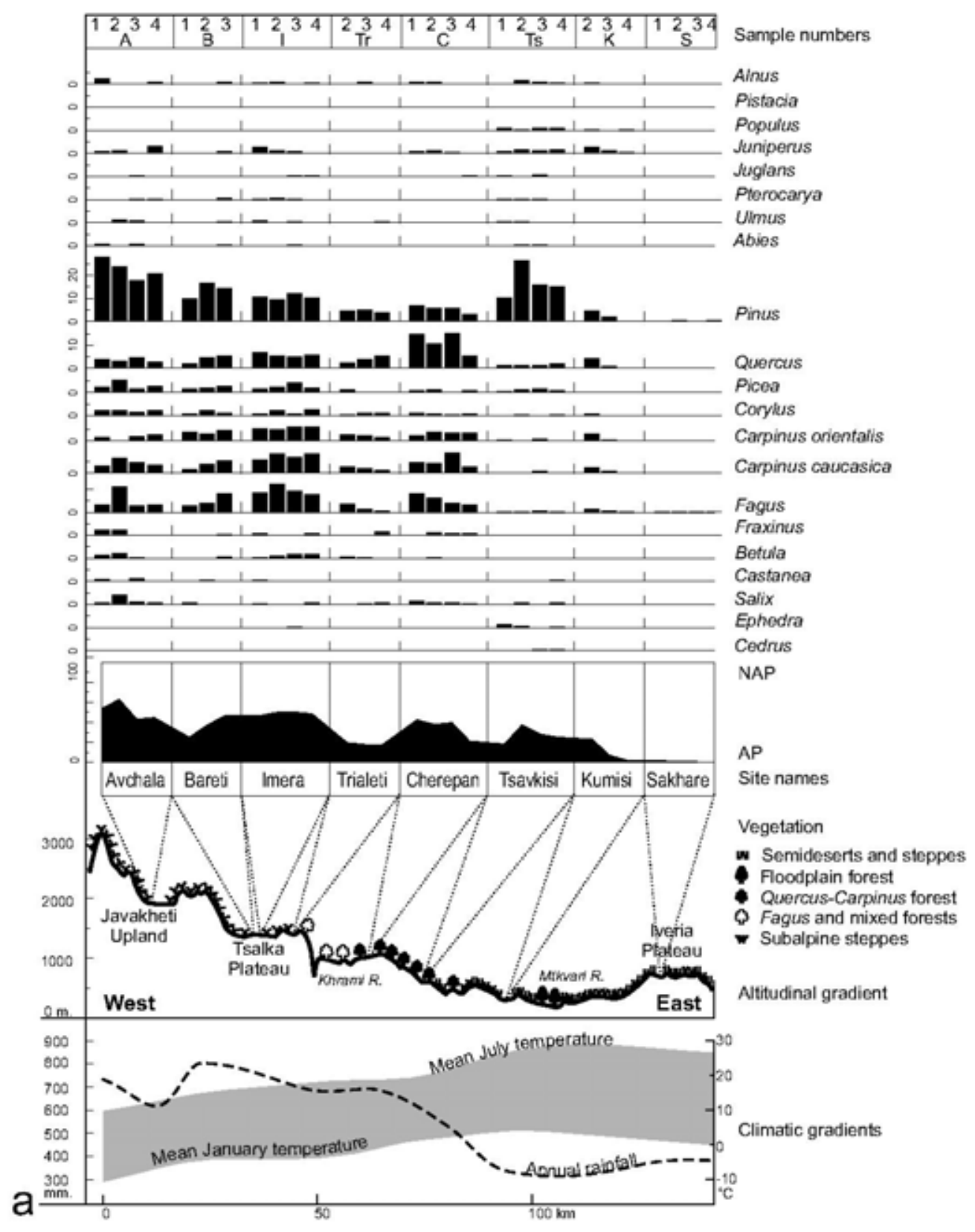

Figure 3(a). Diagram of altitudinal and climatic gradients, arboreal pollen (AP) to non-arboreal pollen (NAP) ratios and percentages of selected AP taxa calculated from the dryland pollen sum. Climatic data from SSSR (1964). 


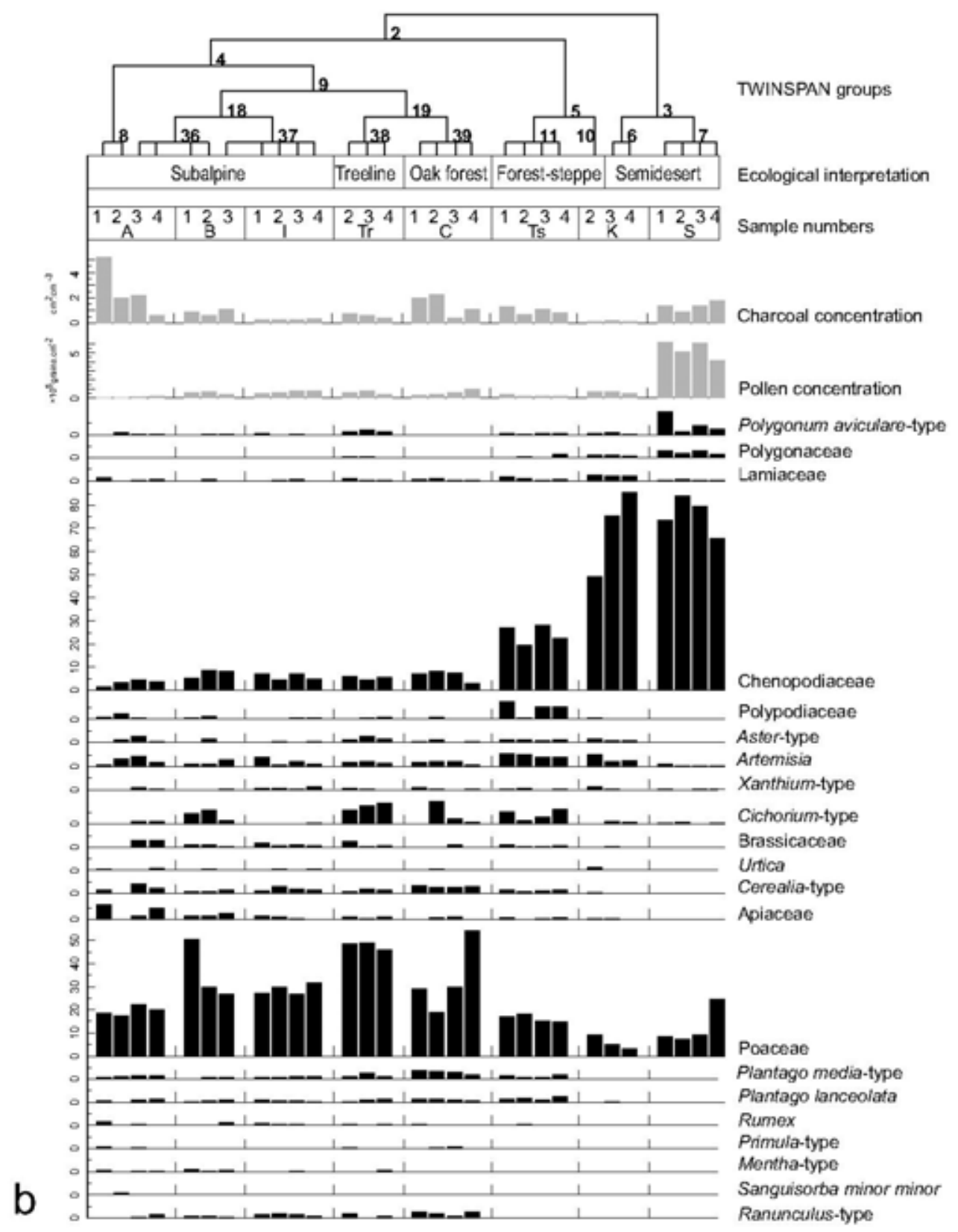

Figure 3(b). Diagram of percentages of selected non-arboreal pollen (NAP) taxa. Pollen and charcoal concentrations, and the results of two-way indicator species analysis (TWINSPAN) are shown at the top of the diagram. TWINSPAN indicators are provided in Table 2. 


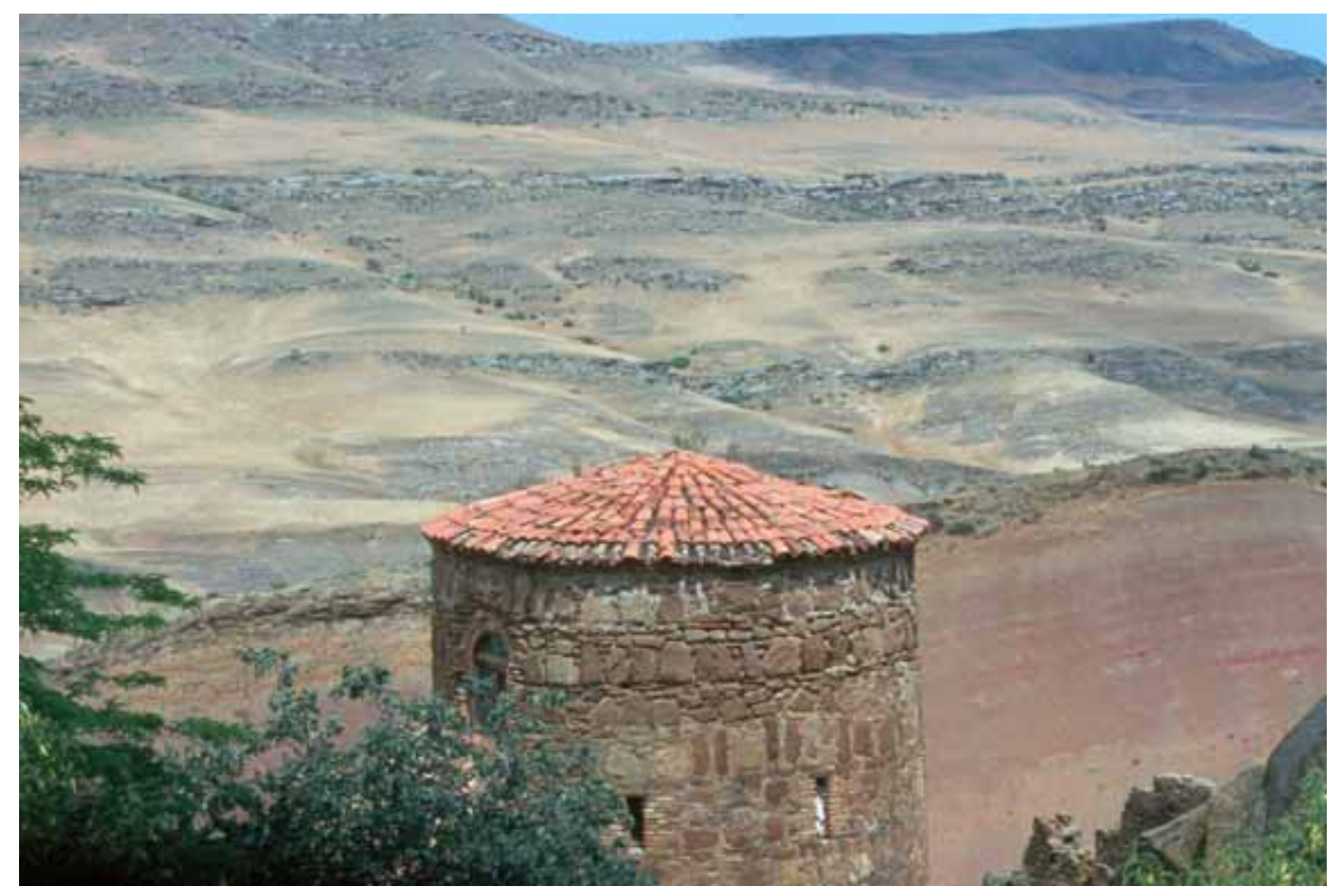

Figure 4. Photograph of the treeless steppes and semideserts of the Udabno-Gareji region, near

Sakhare Tba (site S). In the foreground of the picture is the Davit Gareji monastery, founded in the $6^{\text {th }}$ century A.D., where remnants of the forests that once covered the region can still be found. 


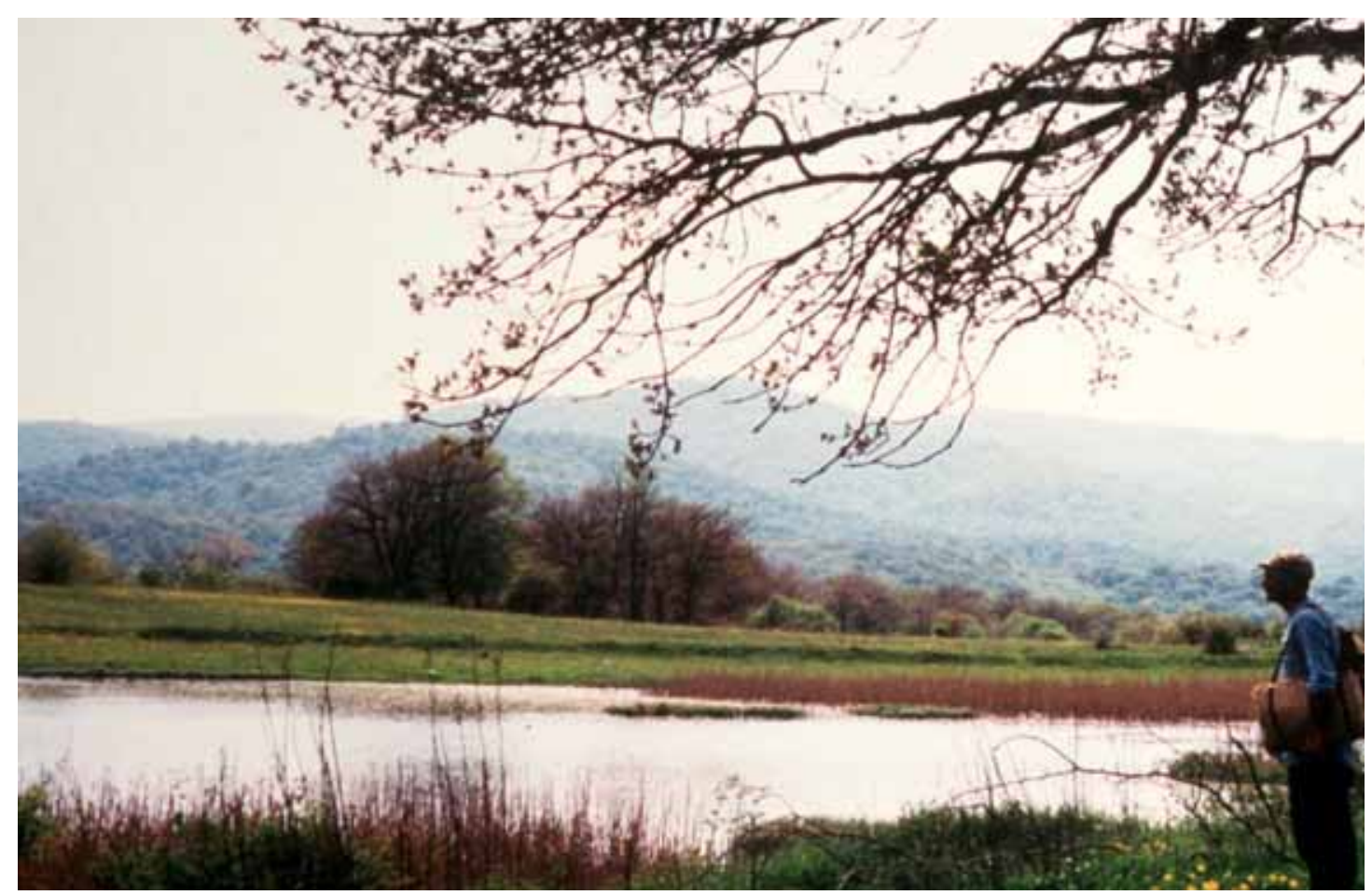

Figure 5. Photograph of Cherepanovis Tba (site C) in the oak forest belt.

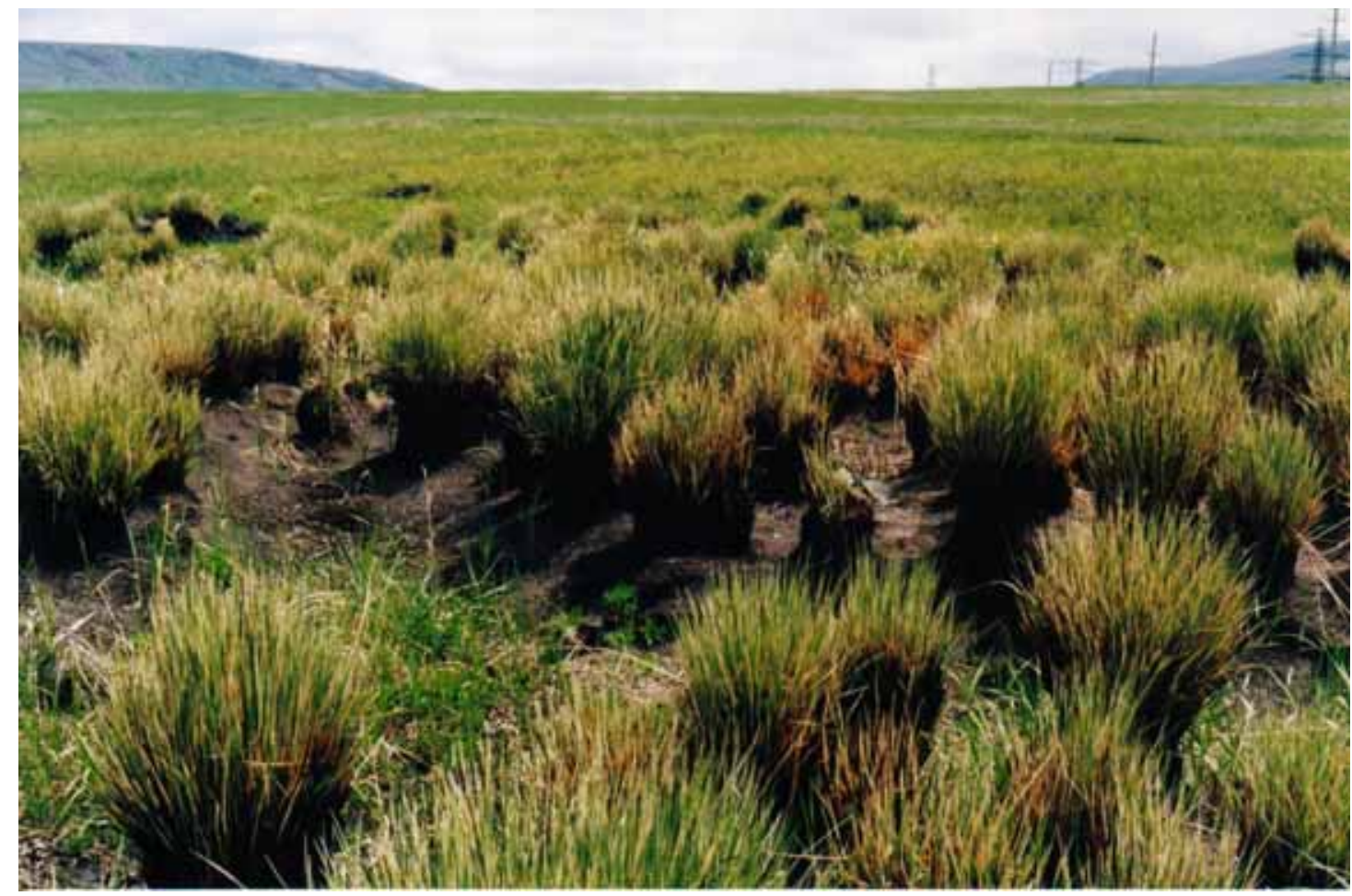

Figure 6. Photograph showing burnt hummocks of Juncellus pannonicus re-sprouting and flowering after a 2001 fire around the margins of subalpine lake Imeras Tba, Tsalka Plateau (site I). 

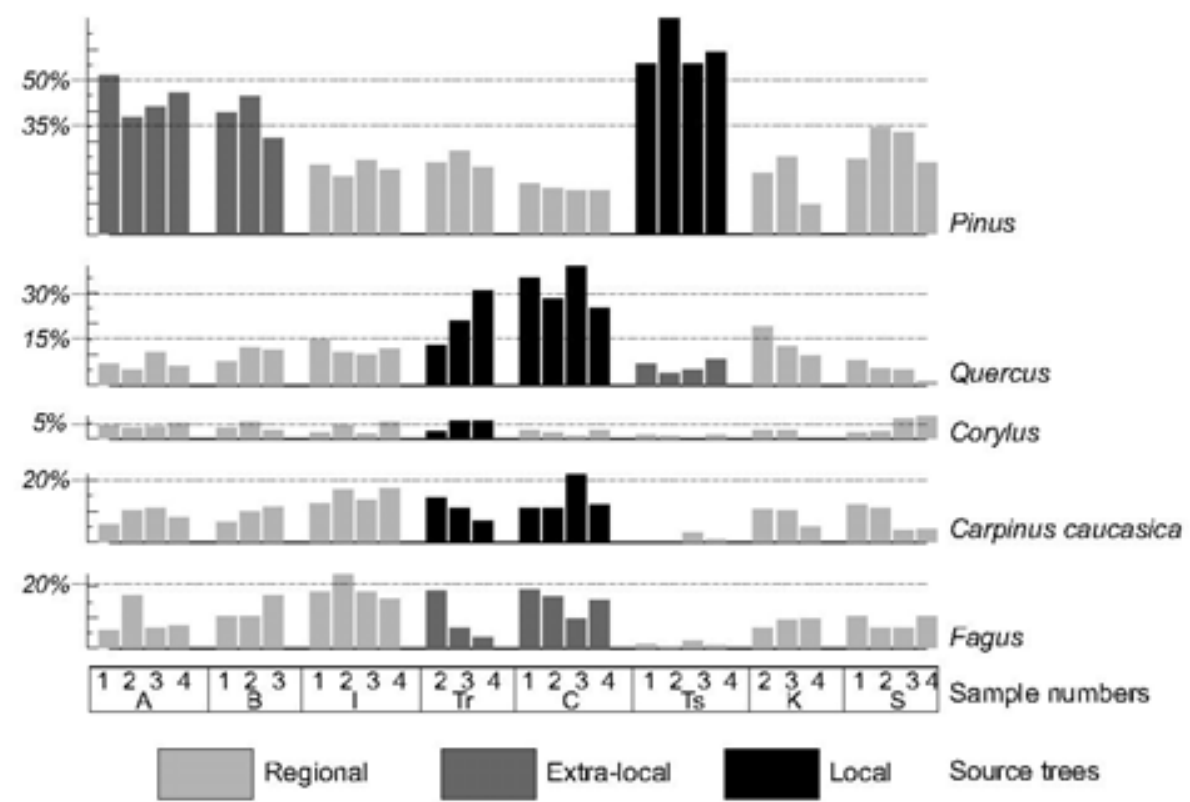

Figure 7. The pollen representation of the dominant forest trees of the study area, calculated from the arboreal pollen sum. Sample numbers follow Figure 3. Histogram bars are shaded according to each taxon's local, extra-local or regional occurrence in the vegetation around the sampling site, and the horizontal lines are the threshold values described in the text. 


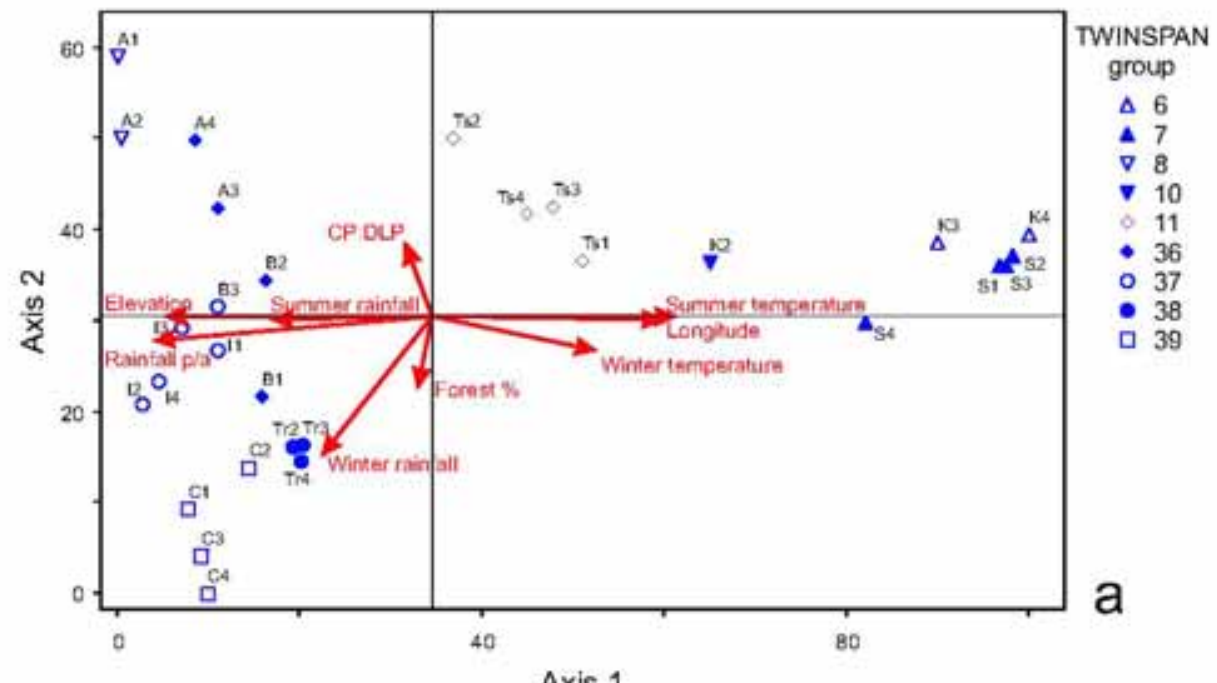

Axis 1

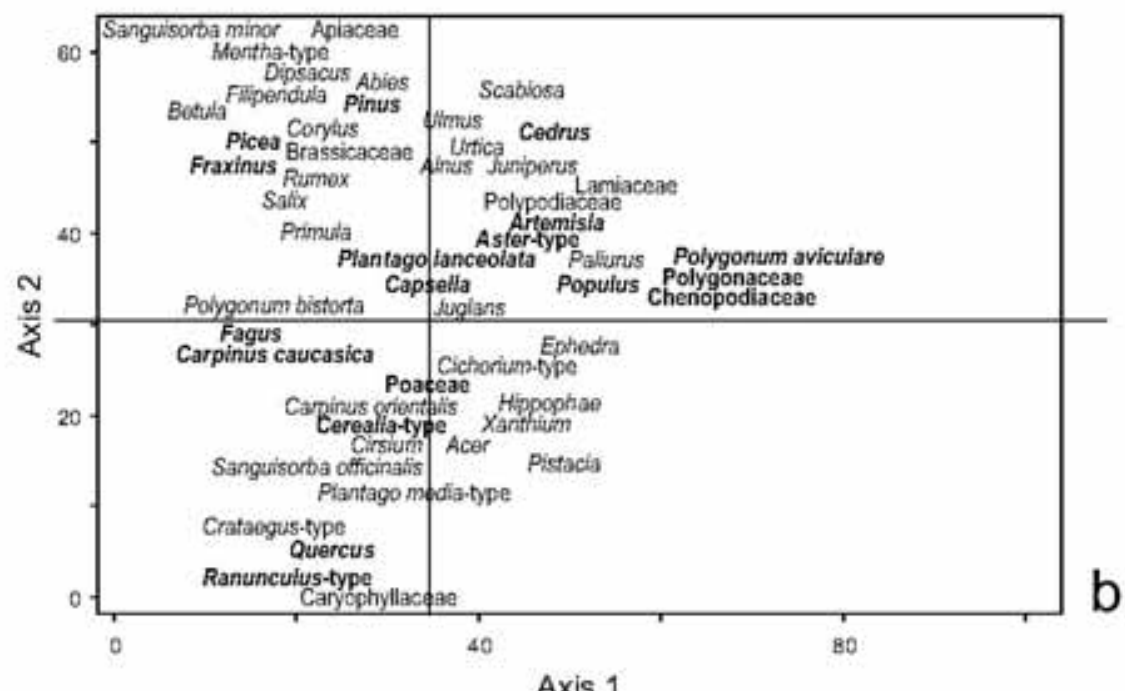

Axis 1

Figure 8(a). Detrended correspondence analysis (DCA) biplot of sample scores, TWINSPAN groups and correlated environmental variables $\left(\mathrm{r}^{2}>0.2\right)$. Samples are labelled by site and sample number (see Fig. 3). CP:DLP refers to the charred particle to dryland pollen concentration ratio.

Figure 8(b). Weightings of selected pollen taxa in the DCA ordination space. Taxa in bold type are TWINSPAN indicators (see Table 2). 